\title{
Evolution of the Triassic shelf in the northern Barents Sea region
}

\author{
Fridtjof Riis, ${ }^{1,4}$ Bjørn A. Lundschien, ${ }^{1}$ Tore Høy, ${ }^{1}$ Atle Mørk ${ }^{2,3}$ \& Mai Britt E. Mørk ${ }^{3}$ \\ 1 Norwegian Petroleum Directorate, Professor Olav Hanssens vei 10, P.O. Box 600, NO-4003 Stavanger, Norway \\ 2 SINTEF Petroleum Research, NO-7465 Trondheim, Norway \\ 3 Department of Geology and Mineral Resources Engineering, Norwegian University of Sciences and Technology, N0-7491 Trondheim, Norway \\ 4 International Research Institute of Stavanger, P.O. Box 8046, NO-4068 Stavanger, Norway
}

\section{Keywords \\ Barents Sea; palaeogeography; paralic; shelf sediment; Svalbard; Triassic. \\ Correspondence \\ Fridtjof Riis, Norwegian Petroleum \\ Directorate, Professor Olav Hanssens vei 10, \\ P.O. Box 600, NO-4003 Stavanger, Norway. \\ E-mail: fridtjof.riis@npd.no}

doi:10.1111/j.1751-8369.2008.00086.x

\begin{abstract}
The interpretation of an unpublished data set of shallow stratigraphic cores and deep, seismic profiles from the northern Barents Shelf has provided new information about the Middle and Late Triassic development of the Barents Shelf and Svalbard. At that time, sediment sources along the eastern and south-eastern margins of the Barents Sea controlled the infilling of a previously deeper shelf area, gradually converting it into a paralic platform. Compared with the eastern source, sediment volumes from other areas were small. In our data, there are no indications of a provenance area north of Svalbard. Progradation from the ESE resulted in diachronous lithostratigraphic boundaries. The organic-rich shales of the Botneheia and Steinkobbe formations were deposited in the remaining deeper shelf areas in the western and north-western Barents Sea shelf, from the Olenekian to the latest Ladinian, by which time the progradation from the ESE had reached eastern Svalbard. In mid-Carnian times, the area of paralic deposits extended from the eastern Barents Sea into the Svalbard Archipelago.
\end{abstract}

By the end of the Permian, the formation of the Uralides was completed, and the Siberian terrain formed an integral part of the Pangean supercontinent (Cocks $\&$ Torsvik 2007). The Late Permian plate tectonic reconstruction of Cocks \& Torsvik (2007) shows that the Barents Sea and Svalbard areas were located on a shelf opening up towards the Panthalassa Ocean, to the north, and surrounded by Pangea towards the south, east and west (Fig. 1). This general palaeogeographic setting prevailed throughout the Early and Middle Triassic, when the shelf areas were gradually filled in by sediments.

Tectonically, the Triassic was a quiet period in the western Barents Sea and Svalbard region. Except for some local fault tectonics, no significant faulting or tectonic unconformities have been mapped. By contrast, the northern and southern Barents Sea basins (Gramberg 1988; Johansen et al. 1992) were strongly subsiding, and formed important depocenters. The total thickness of the Triassic section typically reaches 250-1200 m in Svalbard (Mørk et al. 1982), and increases to 2000-3000 $\mathrm{m}$ in the platform areas of the western Barents Sea, according to regional seismic interpretations of the Norwegian
Petroleum Directorate (NPD; see profiles in Gabrielsen et al. 1990). Relatively uniform thicknesses and a generally shallowing depositional environment suggest that subsidence and sedimentation rates were generally comparable in this western shelf area. "Shelf-edge" and progradational clinoform features on the south-western part of this shelf were first noted by Rønnevik \& Jacobsen (1984), and were described in detail by Rasmussen et al. (1993).

The geometry and facies of these sediments were mainly controlled by erosion and sedimentary input from the borderlands, and by changes in sea level. The major transgressive-regressive sequences in the Barents Sea have been correlated with the Sverdrup Basin in Arctic Canada and other Triassic basins (Mørk et al. 1982; Mørk et al. 1989; Egorov \& Mørk 2000; Mørk \& Smelror 2001), and even globally (Embry 1997). According to Egorov \& Mørk (2000), the major Triassic sequence boundaries are at the base Triassic, base Olenekian, base Middle Triassic (Anisian), base Upper Triassic (Carnian), within the lower Norian, and at the Triassic-Jurassic boundary (Fig. 2). 


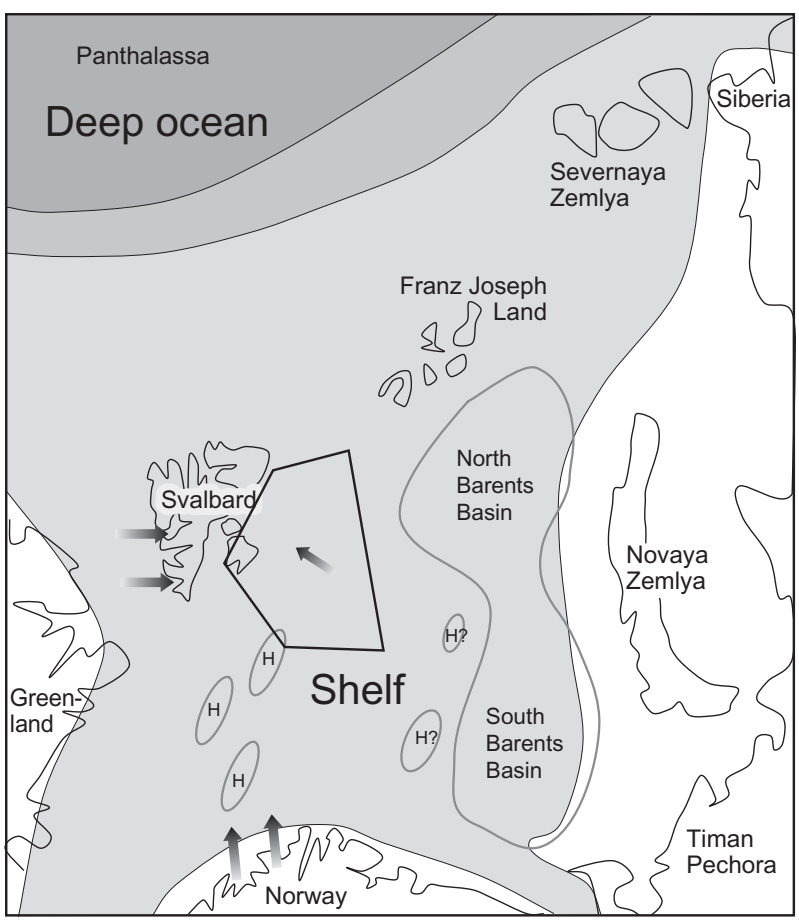

Fig. 1 Reconstruction of the regional setting of the Barents Sea in early Triassic times, showing the continents and the area of Triassic deposition (modified from Cocks \& Torsvik 2007). The study area in the northern Barents Sea is outlined. Major basins with rapid Triassic subsidence and Triassic topographical highs $(\mathrm{H})$ are also shown. Arrows show the directions of the main sediment transport.

The present Triassic lithostratigraphy in the southwestern Barents Sea region (Fig. 2) was defined by Worsley et al. (1988), and the Svalbard nomenclature was revised by Mørk et al. (1999), incorporating the south-western Barents Sea and Svalbard. Whereas the lithostratigraphy of Svalbard is based on rock outcrops, the Triassic lithostratigraphy of the southern Barents Sea is mainly based on well log data and seismic correlation, because of the limited core data available. The Middle and Upper Triassic succession in the southern Barents Sea has been penetrated by 30 exploration wells, and has been sampled by 34 shallow stratigraphic coreholes, of which 13 were drilled by the NPD in the northern Barents Sea (Fig. 3a).

The Lower Triassic lithostratigraphical boundaries are synchronous from Svalbard into the Barents Sea (Fig. 2; Mørk et al. 1999; Mørk \& Smelror 2001), and the sediments represent shallow-open marine environments. Organic-rich mudstones are prevalent in the Middle Triassic succession (Leith et al. 1992); however, this organicrich facies was already developed centrally in the Barents Sea, at the Svalis Dome, in the mid-Olenekian (late Early Triassic), prompting the definition of the Steinkobbe For- mation in that area (Mørk \& Elvebakk 1999). During the Middle Triassic, the coastal sediments of western Spitsbergen (Bravaisberget Formation) graded into deep shelf sediments to the east and south (Botneheia Formation), merging with the organic-rich mudstones of the Steinkobbe Formation in the central Barents Shelf. Along the coast of the Norwegian mainland coastal and deltaic sediments of the Kobbe Formation grade into open shelf deposits in the central Hammerfest Basin (Worsley et al. 1988). A transition from a delta-front setting to a deep shelf is marked by the clinoform belt that will be described below. A change in sedimentation pattern is seen when passing from the Sassendalen Group to the Kapp Toscana Group. The group boundary is time-transgressive in the southern Barents Sea, where the Snadd Formation initiated the group in the early Ladinian, whereas in Svalbard, the correlative Tschermakfjellet and De Geerdalen formations first developed in the Carnian. A poorly constrained "mid" Ladinian age has been suggested at the base of the correlative Skuld Formation on Bjørnøya (Mørk et al. 1990; Fig. 2). A major widespread transgression in the early Norian initiated marine sedimentation of the Wilhelmøya Subgroup in Svalbard, and adjacent areas, and of the correlative Realgrunnen Subgroup in the Barents Sea.

The time-transgressive formation boundaries should be understood and analysed within a regional geological framework. Data from the southern Barents Sea and Svalbard show that the western Barents Sea region evolved from a marine shelf, with a central deeper trough in the Anisian, to a paralic platform in the late Carnian. In the southern Barents Sea, the main sources of sediment appear to be the Baltic Shield in the south, and the Uralides and Novaya Zemlya to the east (Mørk 1999). Most of Svalbard was located in a distal basinal position in the Early and Middle Triassic, and the basin was gradually filled in from the west and from the north (Mørk et al. 1982).

There has been no exploration activity by the oil industry in the northern Barents Sea, and data acquisition and interpretation has been limited to work carried out by the NPD, on behalf of the Norwegian authorities. Because of the small volume of published data, the interpretation of the Triassic palaeogeography of large areas of the northern Barents Sea has not been well constrained.

In this study, we have used unpublished NPD data from the north-western Barents Sea: north of $74^{\circ} 30^{\prime} \mathrm{N}$ and west of $35^{\circ} \mathrm{E}$. The study focusses on the cored Middle and Upper Triassic succession, up to the regional early Norian transgression. Observations and interpretations from the study area are correlated with the geology of Svalbard and the south-western Barents Sea. Our interpretation of the results from shallow stratigraphic drilling and 


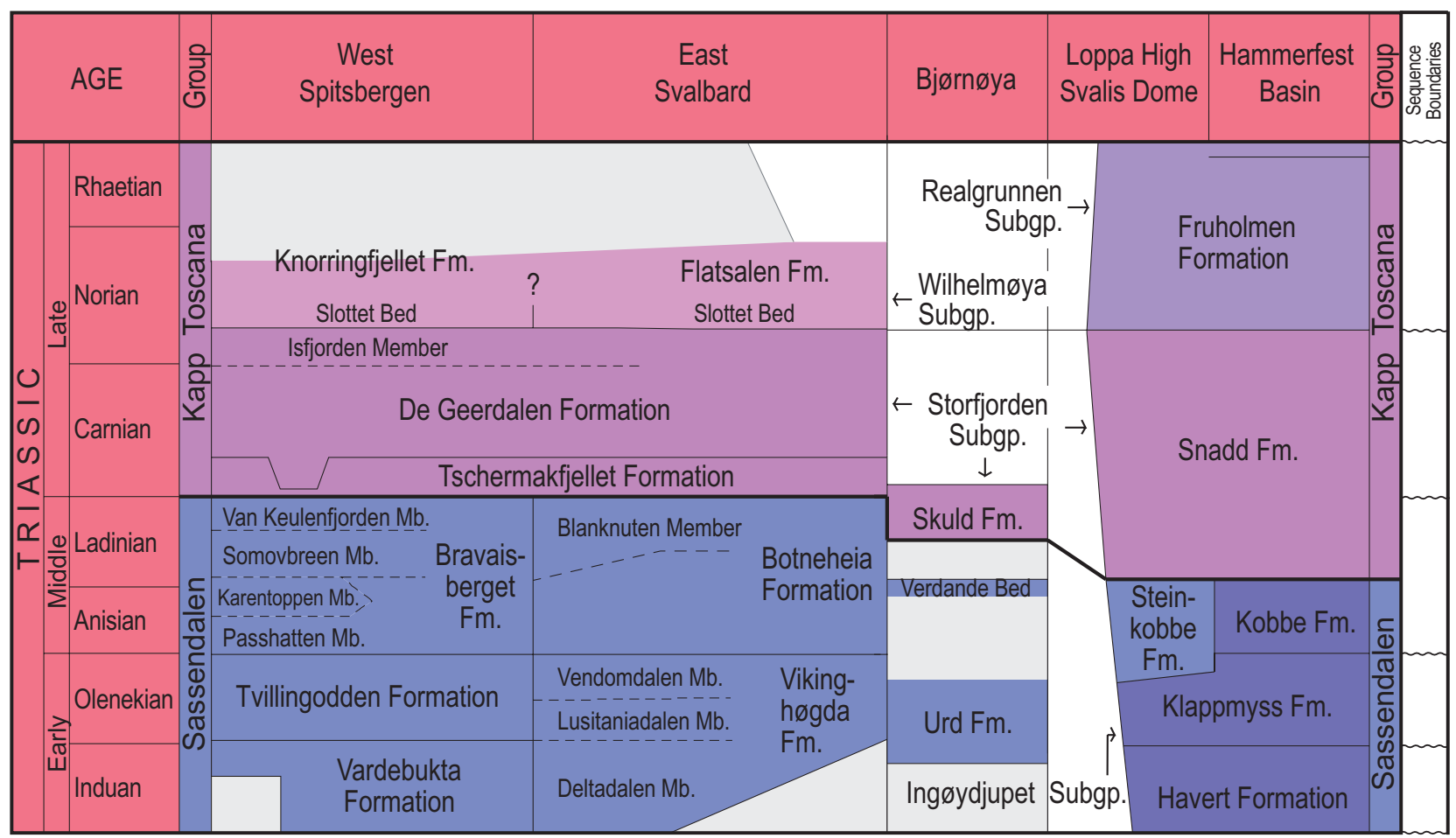

Fig. 2 Overview of the Triassic lithostratigraphy of Svalbard and the southern Barents Sea, simplified from Mørk et al. (1999). The positions of major Boreal Triassic sequence boundaries are based on Egorov \& Mørk (2000).

regional seismic data implies that progradation from eastern and south-eastern provenance areas continued farther to the north and west than has been previously suggested, and that the contribution from the north and north-west was correspondingly smaller. These results are summarized in a palaeogographic reconstruction.

\section{Database and study area}

The study area in the northern Barents Sea is a remote area where no commercial seismic acquisition or drilling has taken place. The main source of conventional seismic data in the study area in the Northern Barents Sea consists of so-far unreleased regional seismic lines acquired by the NPD. The NPD has carried out seismic acquisition since 1973, in order to establish a framework to aid their assessment of hydrocarbon resources. The seismic data coverage in the area is a grid where the distance between the lines typically varies between 5 and $10 \mathrm{~km}$ (Fig. 3b). This is sufficient for regional mapping, but not for detailed prospect evaluation. In this study, the Triassic sequences have been interpreted on most of the seismic lines shown in Fig. 3b, north of $75^{\circ} \mathrm{N}$ and east of $25^{\circ} \mathrm{E}$.

The seismic data quality is generally related to the properties of rocks near the seabed. Most of the region has been an area of net erosion since the Paleogene, and Mesozoic rocks outcrop at the sea floor over vast areas of the northern Barents Sea, covered only by Pleistocene tills with a thickness of a few metres. Where high-velocity and -density Triassic beds or basaltic sills are located near the sea floor, there is poor penetration of the seismic energy into the underlying rocks, resulting in a generally poor quality of data. Figure $3 \mathrm{~b}$ shows that this is the typical situation in the bank areas surrounding Svalbard, and the consequence is that direct and detailed seismic correlation from the Svalbard outcrops into the Barents Sea is difficult. Further east, where acoustic impedances at the sea floor are lower, the seismic data quality is generally much better. The quality is also dependent on the data vintage, and on the acquisition and processing parameters.

The Mesozoic outcrops at the sea floor in the northern Barents Sea range from the Lower Triassic to the Lower Cretaceous. Because of this geological setting, shallow stratigraphic drilling (Rise \& Sættem 1994) can be used to obtain a good coverage of cores. The NPD contracted SINTEF Petroleum Research (formerly IKU) to drill and study Mesozoic stratigraphic cores east and south-east of Svalbard in 1990, 1995, 1998 and 2005 (Fig. 3a). The cores reach a depth of up to $200 \mathrm{~m}$ below the sea floor, and several cores were positioned along geological 

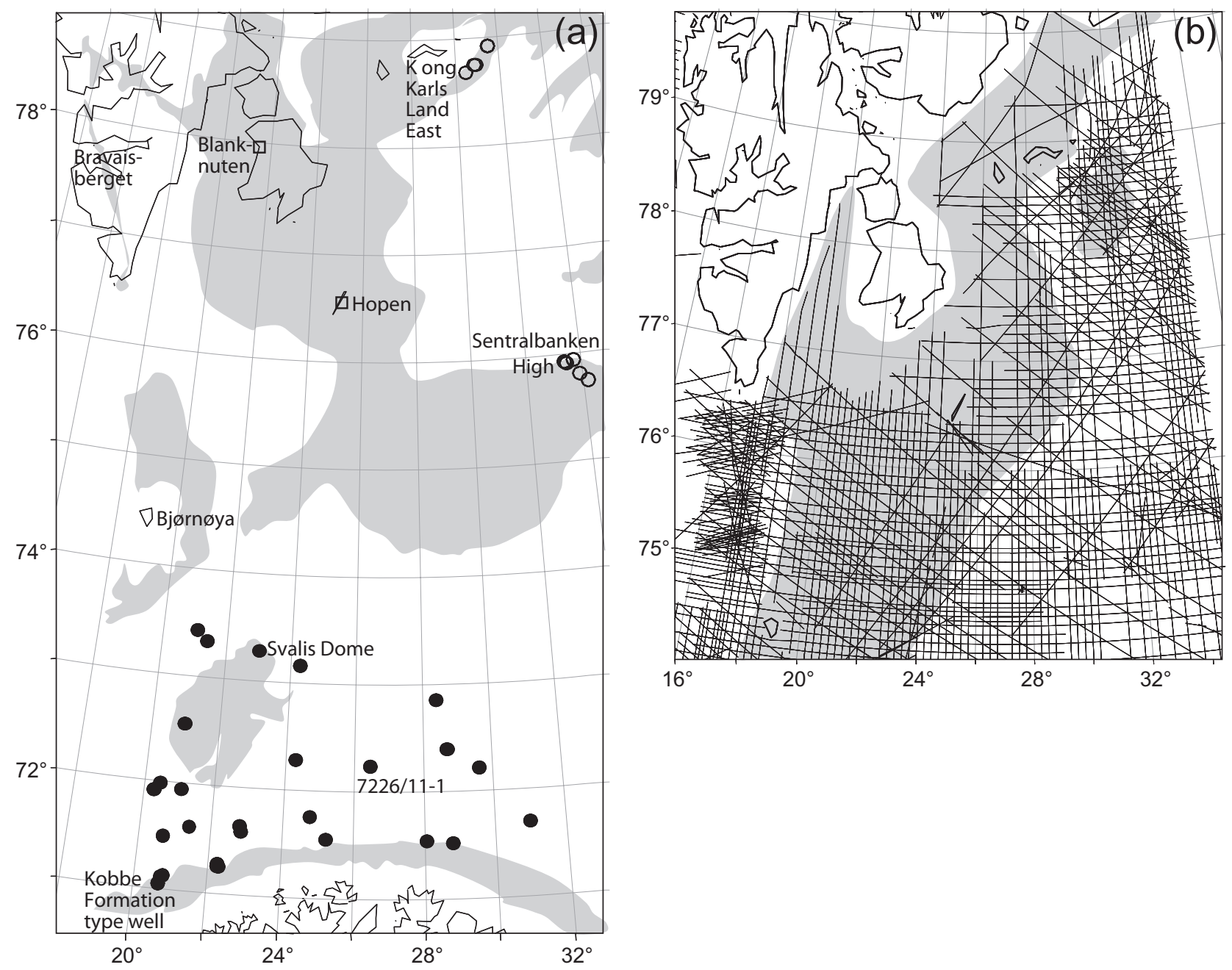

Fig. 3 (a) Outcrop of Triassic rocks in the Barents Sea and Svalbard (shaded grey). Black dots show the locations of exploration wells that have penetrated into the Anisian or stratigraphically deeper layers. Open circles show the locations of the Triassic shallow stratigraphic cores discussed in the text; squares indicate the sample localities on Edgeøya and Hopen. (b) Location of seismic lines acquired by the Norwegian Petroleum Directorate in the northern Barents Sea since 1980. In the shaded areas, the data quality is affected by rocks with high acoustic impedance close to the sea floor.

profiles with structural dips to evaluate and sample the main sequence boundaries, and to obtain as much coverage of the geological succession as possible (Fig. 4). In this way, the most important parts of the section have been sampled at a low cost compared with the drilling of deep exploration wells. These stratigraphic cores constitute the main geological database for the northern Barents Sea.

The present study is the first publication of the core data, and is based on the integration of geological studies of the cores with the regional seismic interpretation. The results are compared with the exposed rocks of Svalbard and the area under exploration in the southern part of the Barents Sea.
Triassic cores used in this study were drilled to obtain information from two different areas located on either side of the Middle Triassic clinoform belt, described below (Fig. 4). The Sentralbanken section on the Sentralbanken High was compiled from five coreholes with nearly $1000 \mathrm{~m}$ of core, ranging in age from the Olenekian to the Norian (Fig. 4). The Kong Karls Land east section consists of five coreholes with $450 \mathrm{~m}$ of core, dating from the late Ladinian to the Carnian (Fig. 5). The cores were described in detail, and were continuously sampled for biostratigraphy and geochemistry by SINTEF Petroleum Research. The biostratigraphic analyses of the core samples were mainly based on palynology carried out by SINTEF Petroleum Research and Applied Petroleum Technology (APT), 
(a)

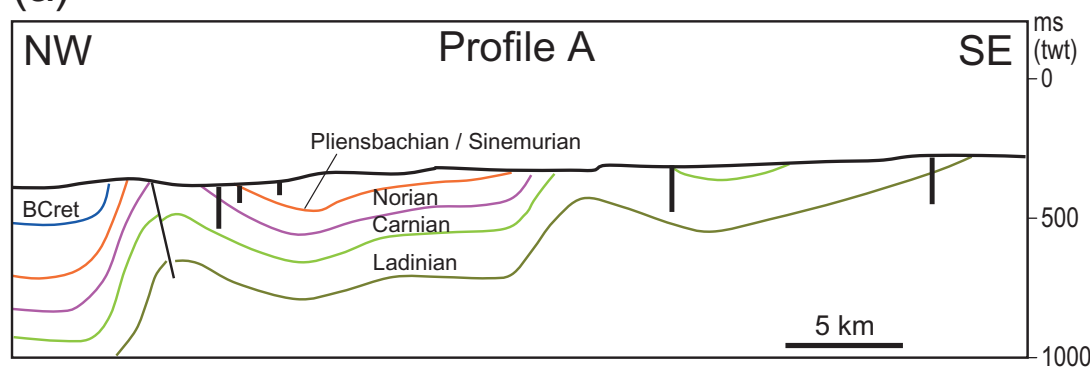

(b)

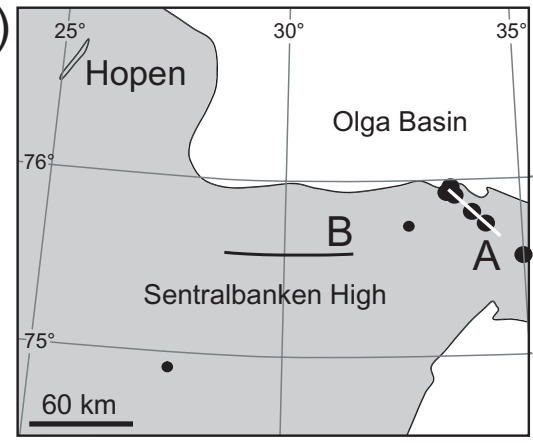

(c)

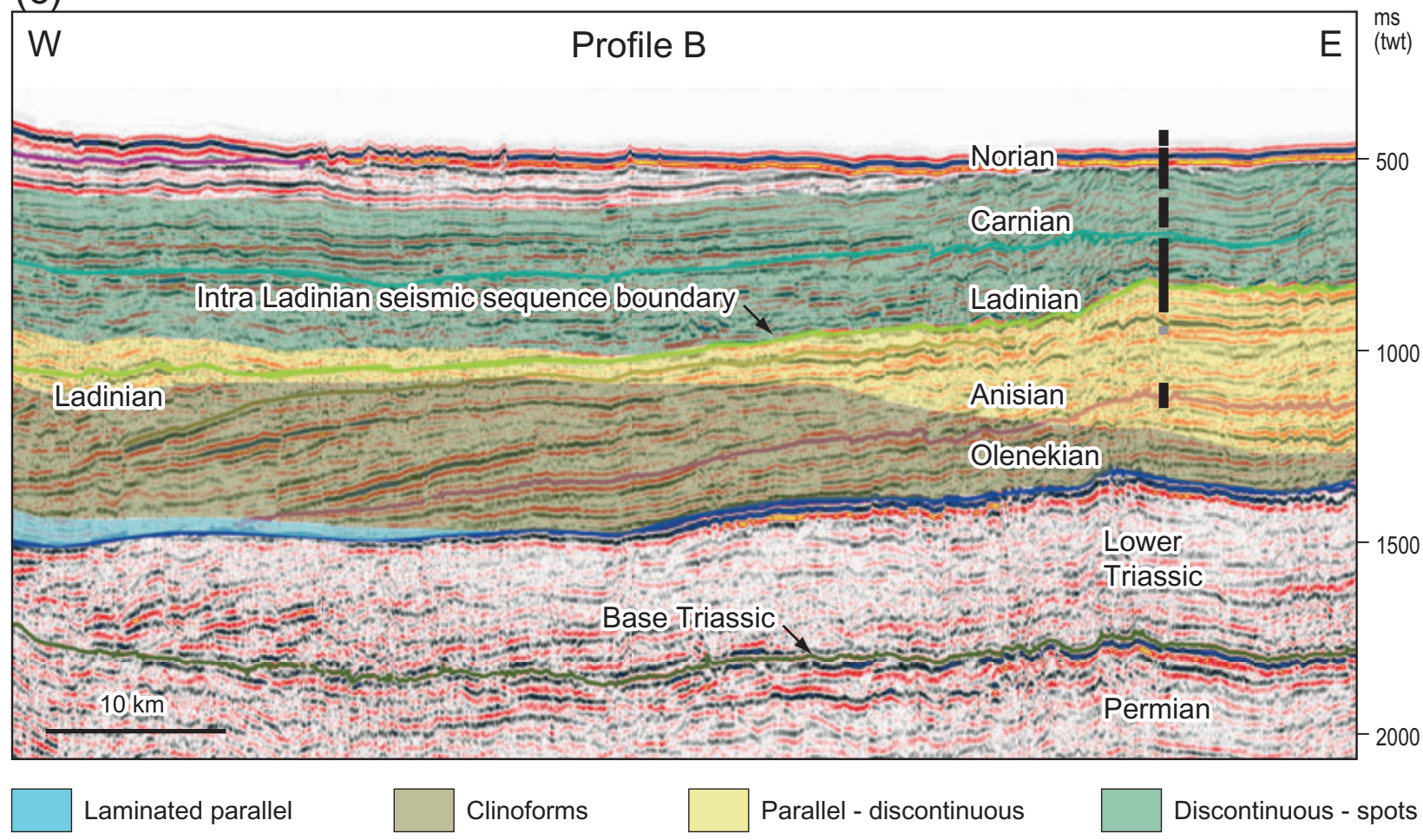

Fig. 4 (a) The Sentralbanken section consists of six boreholes. Five of them are drilled along seismic profile A, shown in (b), and cover an almost complete section from the late Ladinian to the Norian. The last borehole is located at the Olenekian-Anisian boundary, further to the south-east. The anticlinal features were formed by compressional tectonics that post-dates the age of the youngest sedimentary rocks preserved in the area (post-Early Cretaceous). (b) Location of the Sentralbanken section. The Triassic outcrops area is shown in grey. The boreholes included in the section and described in the paper are indicated by the larger black dots. (c) The stratigraphic locations of the coreholes are projected into seismic profile B, where the different seismic facies are interpreted. Laminated parallel reflectors (light blue; facies 1) correspond to an open marine, shallow to deep shelf environment. Large-scale clinoforms (light brown; facies 2), which are occasionally chaotic, slumped layers, correspond to a prodelta environment. Mainly parallel, discontinuous reflectors (yellow; facies 3) in a more proximal setting correspond to a delta-front environment (lower to upper shoreface). Discontinuous reflectors with abundant bright spots (green; facies 4) represent channelled features, indicative of a delta plain setting. The main seismic sequence boundaries are shown. Lithostratigraphically, the light-blue seismic facies is correlated with the Botneheia Formation. The Kobbe Formation is defined as the more proximal part of the Anisian succession (yellow and brown seismic facies). The Snadd Formation comprises the Ladinian and Carnian sequence (yellow and green seismic facies). The precise position of the top Ladinian is not known.

supplemented with a few macrofossil identifications carried out at the University of Hamburg (Wolfgang Weitschat). In this paper, the study of the cores is summarized, and the main results of the biostratigraphic studies are provided.
The petrography of the Upper Triassic samples was correlated with data from outcrops at Svalbard (Fig. 3a) and wells in the southern Barents Sea. The Svalbard samples analysed were collected during an NPD field study in eastern Svalbard in 2007. 


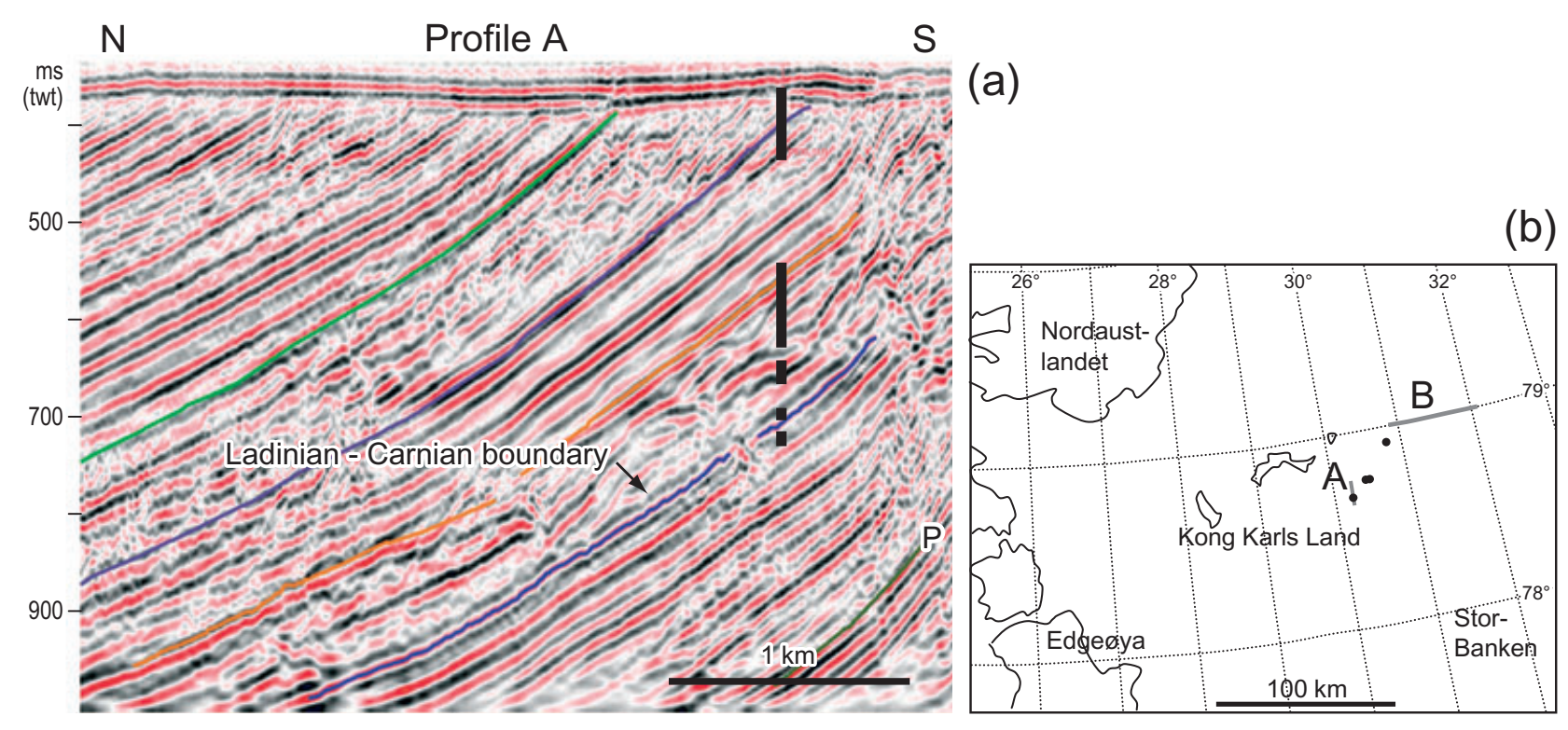

(c)

Profile B

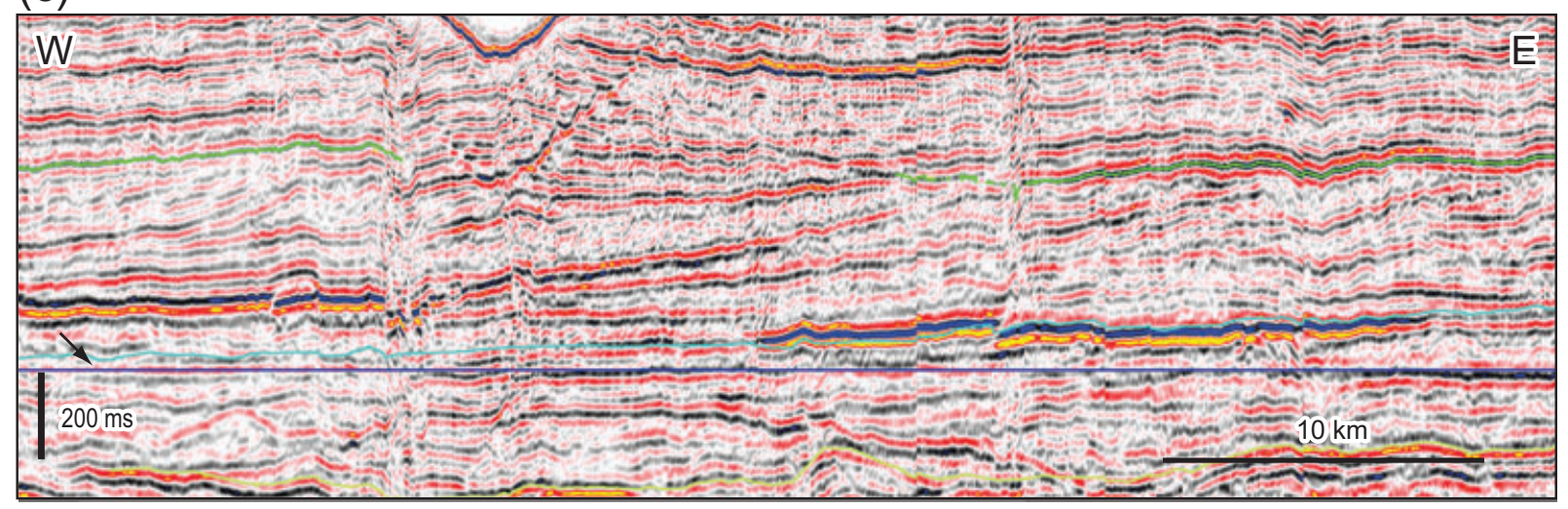

Fig. 5 (a) The Kong Karls Land east section consists of five boreholes. The stratigraphic positions of the cores are projected onto a single seismic line (profile A in panel b). The boundary between the Ladinian Botneheia Formation and the overlying Carnian shales is represented by the blue reflector (Ladinian-Carnian boundary). The cores cover the late Ladinian and early Carnian seismic sequence boundaries. The base Triassic reflector (P) and the top of the Carnian clinoform belt (green horizon) are also shown. (b) Location of the Kong Karls Land east section. (c) Profile B is a seismic section that is flattened on the blue reflector (top of Botneheia Formation, indicated with an arrow). The Carnian clinoform belt is located between the blue reflector and the green line. The green horizon is not a true timeline, as the upper Carnian clinoforms become progressively younger towards the west. The dip of the sea bed and its corresponding seismic multiple in the central part of the section results from the flattening. Strong reflectors are interpreted as basaltic sills. The Snadd Formation continues from the blue reflector up to the sea floor, with a thickness exceeding $1000 \mathrm{~m}$.

\section{Distribution of seismic facies}

For this regional study, four main seismic facies associations are defined, and they are interpreted to represent different depositional environments. The different facies are shown overlying seismic profile B in a central part of the study area (Fig. 4). Changes of seismic facies are indicative of changes in lithological facies. The seismic horizons, which are interpreted to separate geological sequences of different ages, cut across the facies boundaries. Facies changes in each seismic sequence indicate changes in the overall depositional pattern through time, and have been used together with the core data to construct the palaeogographic maps presented in this paper.

The base of the clinoform belt described below can be defined at the blue reflector, which is a prominent seismic sequence boundary in the platform areas in the western Barents Sea. This reflector represents the top of the Havert Formation, near the Induan-Olenekian boundary. In the southern Barents Sea, the Havert Formation consists mainly of marine mudstones and siltstones, coarsening upwards to sandstones in the Nordkapp Basin 
area (well 7226/11-1; NPD 2008). Its upper boundary is interpreted as the transgressive surface of the overlying Klappmyss Formation (Worsley et al. 1988). Prior to this Olenekian transgression, the seismically interpreted main directions of Triassic progradation in the western Barents Sea imply a major source area in the south (i.e., the Baltic Shield).

1. Continuous, parallel-laminated facies. The seismic facies west of the main clinoform belt is characterized by thin sequences with continuous parallel reflectors (blue colour in Fig. 4c). Being located downslope of the prodeltaic clinoforms (facies 1), they are interpreted to represent offshore mudstones. In the palaeogographic reconstruction these areas are mapped as open shelf. This seismic facies has been cored at the Svalis Dome (Steinkobbe Formation; Mørk \& Elvebakk 1999) and in the east of Kong Karls Land (Botneheia Formation), where dark, organic-rich shales were encountered. In a large part of the areas covered by the continuous, parallel-laminated facies, the seismic data quality is poor (Fig. 3a).

2. Large-scale clinoform facies. The most conspicuous feature in Fig. 4c is the belt of large-scale clinoforms that generally dip to the WNW (brown colour in the figure). Individual clinoforms are bounded by continuous reflectors commonly showing high reflectivity. This is typical for the Olenekian and Anisian sequences. Ladinian clinoforms often exhibit a more chaotic reflection pattern, possibly indicating a higher degree of slope instability. The Carnian clinoforms are imaged well in the seismic data in the northern part of the study area (profile B in Fig. 5). The heights of individual clinoforms, from the break of the slope to the termination of the slope at the downlap surface in these profiles, are in the order of $200 \mathrm{~ms}$ (corresponding to approximately $400 \mathrm{~m}$ ), and the corresponding horizontal extension for the Anisian clinoforms is on the order of $15 \mathrm{~km}$ along the line of the section. Consequently, the present dips, without corrections for compaction and later tilt, are slightly more than one degree. The clinoform belt can be mapped in most of the western Barents Sea from 72 to $79^{\circ} \mathrm{N}$, with a general south-west-north-east strike. To the west, the clinoforms downlap towards the offshore shelf facies (blue colour in Fig. $4 \mathrm{c}$ ). To the east, there is a gradual transition from the dipping clinoforms to the horizontally layered delta-front facies (yellow colour in Fig. 4c).

The core data from the typically developed clinoform belt are very limited. The geometry of the reflectors indicate a consistent and large-scale sedimentary progradation towards deeper water in the WNW. It is likely that the difference in water depth is related to the height of the individual clinoforms, typically $300-400 \mathrm{~m}$. Based on the seismic data, the clinoforms are interpreted to represent the outer slope of thick deposits, which were built out into the Barents Sea, and are interpreted as prodelta facies. This interpretation is consistent with the core data of the different facies both east and west of the clinoform belt.

3. Discontinuous, parallel-laminated facies. East of the clinoform belt in Fig. 4c, the clinoform facies grades into a more heterogeneous facies with subhorizontal, subparallel reflectors with variable reflectivity (yellow colour in Fig. 4c). Individual reflectors are less continuous and more undulating than in the deep-water facies (facies 2). With a more proximal location to the sediment source, relative to the prodelta, this facies is interpreted as belonging to a general delta-front setting. The heterogeneous, subparallel seismic facies has been cored in the Anisian and Ladinian section of the Sentralbanken High, and in the Carnian section from eastern Kong Karls Land, where sediments from lower to upper shoreface environments were encountered.

4. Heterogeneous, channelled facies. The typical heterogeneous and channelled facies is easy to recognize because of the high-reflectivity "bright spots", which occur at different levels throughout a section of discontinuous to continuous, undulating reflectors of variable reflectivity (green colour in Fig. 4c). Based on comparison with 3D seismic surveys in the Upper Triassic section further south in the Barents Sea (e.g., Laursen et al. 2006), the bright spots are interpreted as channel systems. The heterogeneity suggests a rapid variation of depositional facies. This seismic facies has been extensively cored on the Sentralbanken High, and a general delta plain environment was interpreted (described below). The thick section of heterogeneous, channelled facies in the Carnian succession is typical for the study area in the northern Barents Sea (Fig. 4c). The distance from the clinoform belt (prodelta) to the channelled facies (delta plain) appears to be less in the LadinianCarnian than in the Anisian successions, as also noted in the palaeogographical discussion (below).

\section{The Sentralbanken cored section}

The Sentralbanken High was selected for shallow stratigraphic drilling because it has good subcrops at the sea floor of the Middle and Upper Triassic succession. The seismic quality in the area is good, and there is a reliable correlation between the seismic reflectors and the corresponding geological boundaries seen in the drilled cores. The high is transected by a system of folds and mainly compressional faults, which deform the preserved 
Mesozoic rocks in this area. The geological profile in Fig. 4a is based on a seismic line that intersects two of these compressional structures. Five of the coreholes are projected onto the profile. The figure shows that the base Cretaceous horizon takes part in the deformation, and this is also the case for the overlying Lower Cretaceous reflectors. This implies that the main phase of the compressional deformation of the Sentralbanken High postdates the Early Cretaceous. In our regional studies, we have not observed synsedimentary movement on the faults in the Triassic succession. In contrast to the western highs in the Barents Sea, the deeper seismic sections indicate that the Sentralbanken High is an uplifted part of the platform area, and does not represent a buried basement high, a conclusion that was also reached by Gabrielsen et al. (1990). The Triassic geological setting in this section is interpreted to be representative for a large area east of the clinoform belt.

\section{The Klappmyss and Kobbe formations}

The time thickness of the Anisian seismic sequence increases to $300 \mathrm{~ms}$, corresponding to approximately $600 \mathrm{~m}$, in the eastern part of the profile shown in Fig. 4c. The lowermost part, including the Olenekian-Anisian boundary, has been cored. There is also a short core higher up in the section showing shallow marine conditions. The short core is not described further in this paper. The cores penetrated the parallel, discontinuous facies (yellow colour in Fig. 4c) east of the main clinoform belt.

In the stratigraphically deepest core, the lower unit (below the Olenekian-Anisian boundary) is palynologically dated as late Olenekian, and is assigned to the Klappmyss Formation of Worsley et al. (1988). It consists of dark-grey to green siltstones with interbeds of very fine-grained sandstones (Fig. 6). The sandstone beds generally have sharp bases and fine upwards. Palynodebris and trace fossils indicate a marine depositional environment: both the low abundance and low diversity of the ichnofauna may suggest reduced oxic conditions in the bottom water, or rapid sedimentation. The sandstone beds may represent deposition from minor, possibly storm-generated, turbidity currents. The unit is interpreted as having been deposited below the storm-wave base on a moderately shallow shelf, with reduced oxic sea-bottom conditions, and rapid depositional rates.

The unit above the Olenekian-Anisian boundary, included in the Kobbe Formation of Worsley et al. (1988), starts with a dark-grey claystone of poor to fair organic richness in type-IV kerogen, resting on an erosive top surface of the Klappmyss Formation. Upwards, the unit grades into a clayey siltstone with thin, generally sharp-based and upward-fining sandstone interbeds (Fig. 6). Bioturbation is sparse and of low diversity. Ammonoids and palynomorphs of early Anisian age occur in the claystone interval. The lowermost part of the Anisian succession seems to be missing, as may also be the case in outcrops over most of Svalbard (Mørk et al. 1992). The siltstone interval is palynologically dated to the middle Anisian. A phosphate conglomerate is present, and resembles contemporaneous deposits in Svalbard (Mørk et al. 1982; Krajewski 2000). The dark-grey claystone with fair organic content in its lower part suggests deposition under mostly low-energy anoxic conditions. A slight upward increase in energy level and ventilation is indicated by the increased content of silt and sandstones, and by slightly more bioturbation. The depositional environment for this unit is interpreted as being a deep, low-oxic shelf for the claystone part, gradually shallowing upwards to an environment within the reach of episodic storm influence, and slightly more ventilated, but still with reduced oxic conditions.

The abrupt facies change from sandy siltstones of the Klappmyss Formation to dark organic-rich claystones of the Kobbe Formation across an erosive boundary, and the possible lack of a lowermost Anisian succession above the boundary, may represent a major transgression, where the erosive surface represents reworking during transgression. There are no indications of subaerial exposure at the boundary, as has also been reported on Svalbard (Mørk et al. 1982; Mørk et al. 1999). The boundary coincides with a prominent seismic sequence boundary that can be mapped regionally in the Barents shelf, and is interpreted to correspond to a major early Anisian transgressive episode throughout the Arctic (Mørk et al. 1989; Mørk et al. 1992; Mørk \& Smelror 2001).

\section{The Snadd Formation}

Three long boreholes cover the upper part of the Ladinian and most of the Carnian sections, respectively (Figs. 4, 6).

The stratigraphically deepest core is dated as late Ladinian by palynology, and is included within the Snadd Formation of Worsley et al. (1988). It commences with a unit consisting of two upward-coarsening sequences grading from slightly silty mudstone to siltstone. Sparse, but upwards increasing bioturbation in both sequences, as well as trace fossils in the upper sequence, are indicative of open marine conditions. The two upwardcoarsening sequences may represent prograding lobes within a delta system. At the core locality, probably only the prodelta parts of the lobes are present.

A radical change in depositional environment is recorded on top of the siltstone unit described above. 


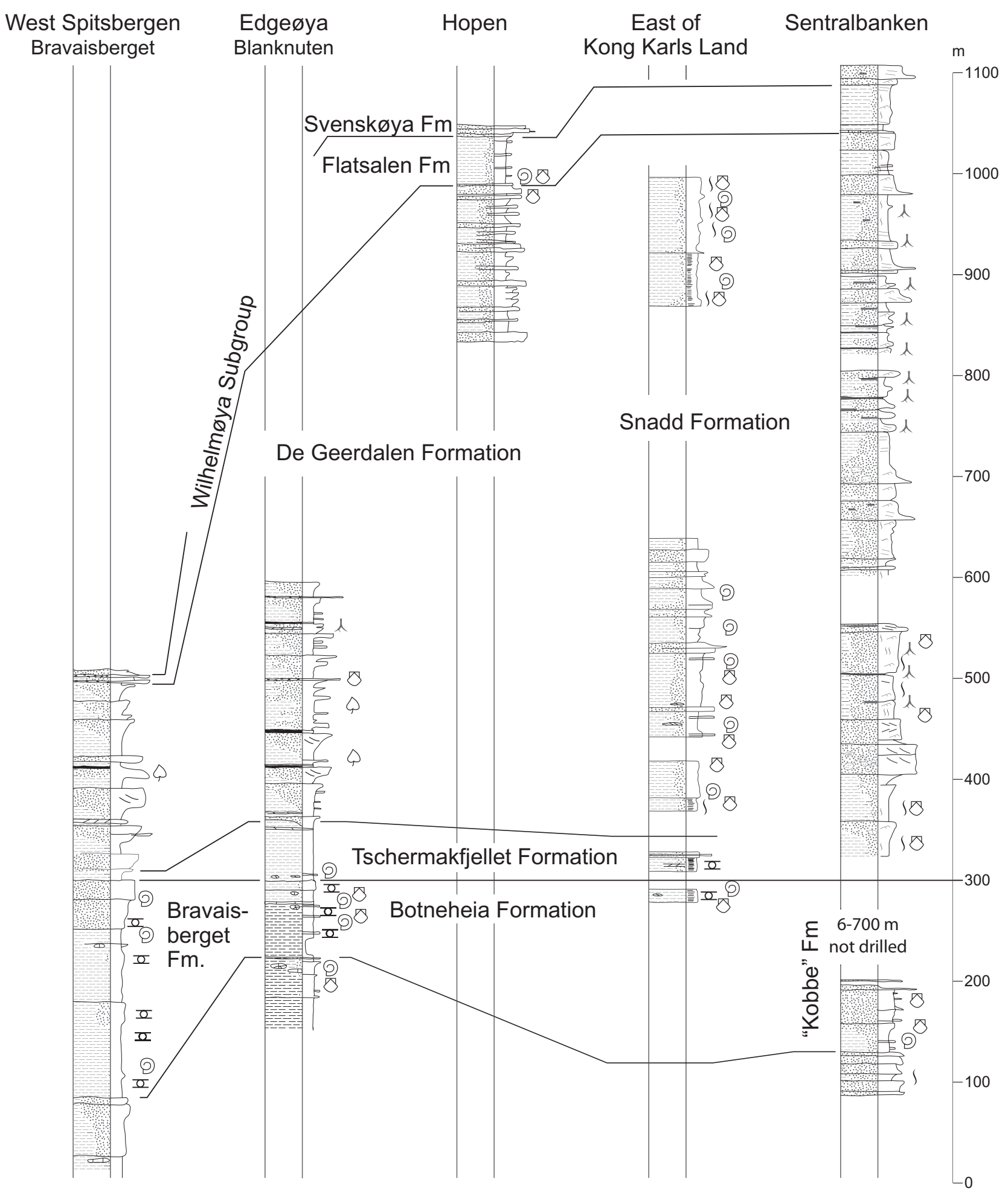

Fig. 6 Interpreted sedimentological sections of the Middle and Upper Triassic strata in Svalbard, and the cored sections of north-east Kong Karls Land and Sentralbanken High. The legend is given in Fig. 7. 


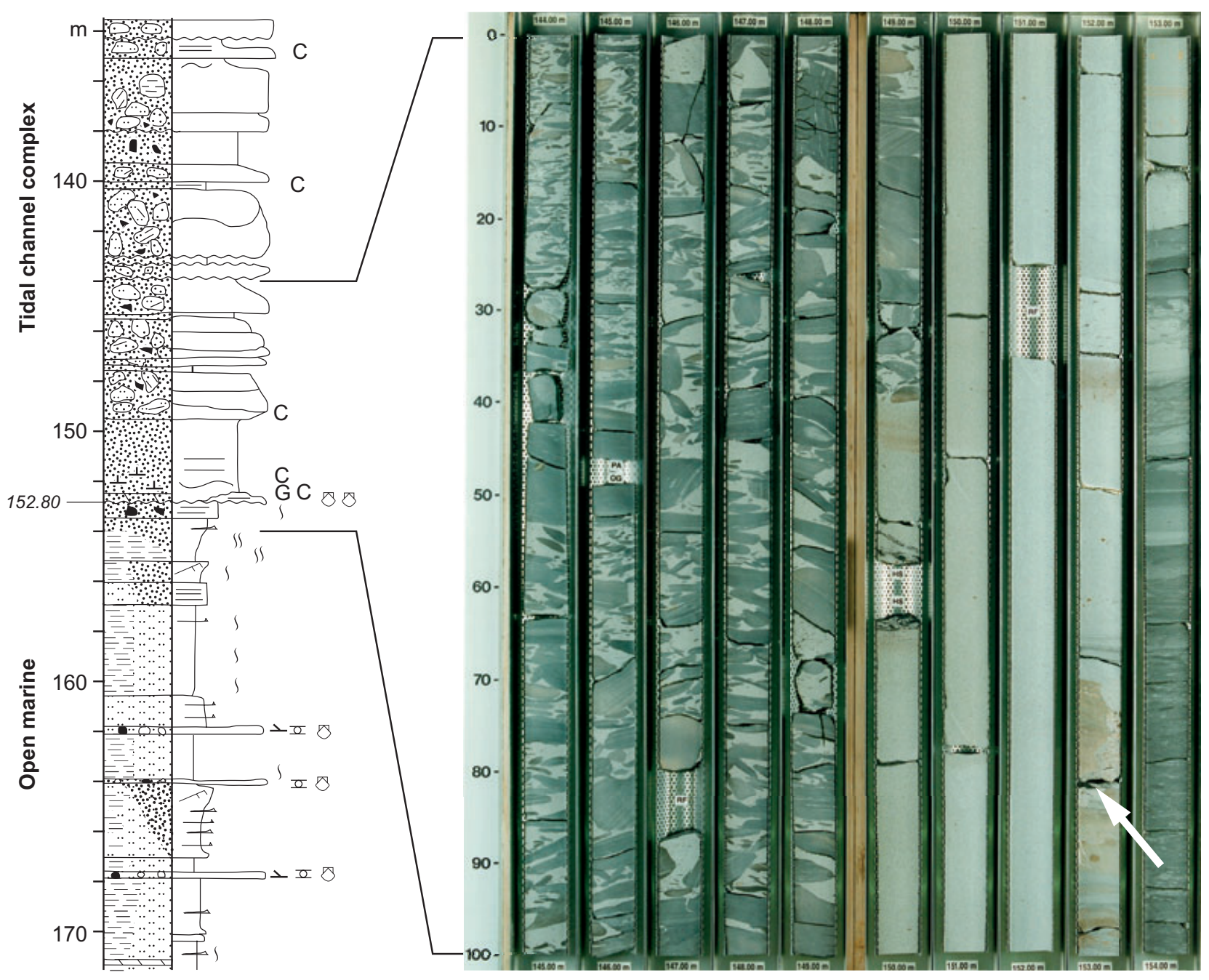

\begin{tabular}{|c|c|c|c|c|c|}
\hline$\because 0$ & Conglomerate & $0 \Leftrightarrow$ & Nodule / septarian nodule & $\perp$ & Calcite cementation \\
\hline i & Sand- and siltstone & $\theta_{. .0}$ & Sediment clasts & $\perp$ & Siderite cementation \\
\hline$\because \cdots \cdots \cdot$ & Siltstone & 列 & Ripple lamination & C & Cole debris \\
\hline$E=-=-1$ & Mud and cavctono & 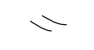 & Cross-bedding & G & Glauconite \\
\hline$E=-=$ & 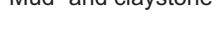 & & Lamination & (2) & Ammonoids \\
\hline \begin{tabular}{|l|l|}
1 & 1 \\
\end{tabular} & Limestone & & Mud waves & $\varnothing$ & Bivalves \\
\hline$\frac{1}{27}$ & Dolomite & $\longrightarrow$ & Fining up lamination & $Q_{P}$ & Plant fossils \\
\hline 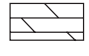 & Siderite & $\longrightarrow$ & Lenticular lamination & 入 & Roots \\
\hline E & Coal & z & Phosphate nodules & $\int$ & Bioturbation \\
\hline
\end{tabular}

Fig. 7 Core photos and sedimentological log from the upper Ladinian Sentralbanken section. The cores show an abrupt change from an open marine to a deltaic tidal depositional environment at $152.8 \mathrm{~m}$ depth (arrow). This change may indicate a facies shift of regional extent, and is interpreted to correspond with a regional seismic sequence boundary separating an open marine and delta plain seismic facies (the green reflector in Fig. 4c, profile B).

Above an erosional surface at $152.8 \mathrm{~m}$ depth in the core (Fig. 7), there is a thin basal calcite- and siderite-cemented bioclastic-rich sandstone bed. This bed is followed by a series of stacked intraformational conglomerates consist- ing of sandstone and siltstone clasts organized in upwardfining motifs, with an upward diminishing trend in clast size. Bioturbation is completely lacking within this unit, indicating unfavourable living conditions. The unit as a 
whole may represent a channel system, possibly within a deltaic tidal depositional environment.

The abrupt change from an open marine to a deltaic depositional environment, with a possible erosional unconformity in between, may be regionally significant. A base-level fall may have forced the incision and deposition of deltaic or estuarine facies, on top of open-marine facies, during the subsequent base-level rise. If the boundary between the two units described above represents a regional sequence boundary, one would expect it to be expressed in the seismic data. In Fig. 4c, the approximate stratigraphic positions of the cores are projected onto the seismic section, which crosses the clinoform belt some $50 \mathrm{~km}$ west of the drilling localities. As the true location of the cores is further east, the seismic section does not give an exact representation of the reflector pattern in the cores, but it is clear that the green seismic facies correlates with the long core section above the erosional surface. The green seismic horizon is interpreted to be at, or close to, the boundary in the core. The horizon marks the boundary between the green (channelled) facies and the yellow (parallel, discontinuous) facies over a large area, and is interpreted as a possible sequence boundary.

The possible deltaic channel system overlying the erosional surface in the core is in turn overlain by a unit that consists of fine- to medium-grained sandstones, interlaminated with coal debris. Bioturbation is completely lacking. Thin siderite-cemented beds occur frequently throughout the unit. The abundant coal debris and lack of marine ichnofossils may be indicative of a non-marine depositional environment. Thin upward-fining beds in the lower part of the unit are interpreted as interchannel deposits in a delta plain setting, which develop upwards into a barrier bar complex represented by thicker, low-angle cross-bedded sandstone beds.

The upper part of this core consists of silty shales, siltstones and sandstones, forming a series of upwardcoarsening subunits, often capped by coal beds. The lower, fine-grained parts of each subunit are often strongly bioturbated. Upward-coarsening sequences with marine bioturbation and coal layers on top may be indicative of a lower delta plain or estuarine depositional environment. An association of coal beds and roots penetrating deep into marine bioturbated beds may point towards a tidal flat with heavy vegetation. The unit is interpreted as being deposited in a lower delta plain setting, where fully continental or elevated delta plain conditions never developed. The core resembles the Snadd Formation in the southern Barents Sea (Worsley et al. 1988), which in that area dates from the Ladinian to the early Norian.
The next two cores in the Sentralbanken section are dated by palynology as Early Carnian, whereas the uppermost part passes into the Late Carnian. Both cores consist dominantly of upward-fining sandstones, some of which contain intraformational conglomerates, although some upward-coarsening sandstone beds also occur. Coal debris and root horizons are abundant, and some soil profiles are also present. Indicators of marine influence are generally lacking. The cores are interpreted to represent a mid to upper delta plain depositional environment, with the upward-fining sandstones representing channel fills.

The entire Carnian succession resembles the Snadd Formation, but it also bears a strong similarity to the De Geerdalen Formation in its closest onshore exposures at Hopen.

\section{Carnian-Norian transition}

The stratigraphically highest Triassic core from the Sentralbanken section is dated as Carnian-Norian. The lower unit in the core is dominated by sandstones, and is dated to the Late Carnian by palynology. The sandstones contain ripple-laminated and low-angle cross-laminated beds, some of which are amalgamated in sequences as thick as $2 \mathrm{~m}$. One bed has a siderite and mud-clast conglomeratic lag at its base. Coal debris and plant fragments are present on a few bed surfaces. Bioturbation is generally lacking, except for the uppermost bed, which is intensely bioturbated, and calcite and siderite cemented. A delta plain environment is suggested for this unit, because of the general lack of bioturbation and the presence of coal debris and plant fragments. The thicker sandstone beds, especially the one with the siderite and mud-clast conglomeratic lag, may represent fluvial channel fills.

\section{Overlying units (Flatsalen and Svenskøya formations)}

In the upper part of the core described above, the intense bioturbation, and calcite and siderite cementation, of the top bed is interpreted as a result of a transgression. The unit can be correlated with the uppermost part of the de Geerdalen Formation on Svalbard, and with the Snadd Formation in the Barents Sea, and the top bed resembles the Slottet Bed, which initiates the Wilhelmøya Subgroup on Svalbard (Mørk et al. 1999).

On top of the Slottet Bed equivalent, a mudstonedominated unit gradually passes upwards into sandstones. This unit is dated by palynology as early Norian. These sediments are interpreted as a new regressive succession that evolved above the transgressed delta plain surface at the top of the Snadd Formation. The 
mudstone unit is correlated with the Flatsalen Formation, and the overlying sandy unit is correlated with the Svenskøya Formation in Svalbard (Mørk et al. 1999).

The condensed transgressive bed (?Slottet Bed) on top of the delta-plain sandstone, within the early Norian, coincides with a seismic sequence boundary. There is a change in seismic facies from the Snadd Formation, through the more shaly Flatsalen Formation, to the sandy Svenskøya Formation. In large parts of the study area in the north-western Barents Sea, the Carnian-Norian transition has been eroded or is situated close to the sea floor. Consequently, it is not easy to generate a regional map of this sequence boundary. The surface is interpreted to correspond to the regional early Norian transgression that initiated a major sedimentological shift in the Barents Shelf area, including Svalbard. This transgression led to a long period of shallow shelf conditions, on which mature sandstone complexes evolved during the latest Triassic and Early Jurassic (Bergan \& Knarud 1992; Mørk et al. 1999; Worsley 2008, this issue).

\section{The Kong Karls Land east cored section}

The area selected for the drilling of stratigraphic cores, east of Kong Karls Land and north of Storbanken (Fig. 5), is localized on a salt-cored structure, which brings Middle and Upper Triassic rocks to the sea floor in an area west of the Middle Triassic clinoform belt. The main salt movement took place after the deposition of the Triassic succession, and our regional interpretation has not yet revealed any significant anomalies in the Middle/Upper Triassic seismic pattern that can be related to the initial salt basin, or to later salt movement. The quality of the seismic data in the area is generally good, and in most cases enables a reliable correlation between the drilled Triassic sections and the surrounding platform.

In the Kong Karls Land east section, one short core was obtained from the top of the uppermost Ladinian succession, which is developed as a dark-grey, organic-rich mudstone, representing the Botneheia Formation. The other four coreholes were drilled on three different Carnian seismic sequences, within an approximately 700-m-thick section (Fig. 5a).

\section{The Botneheia Formation}

Throughout Svalbard, a pronounced lithological change takes place at the transition between the Botneheia Formation of the Sassendalen Group and the Tschermakfjellet Formation of the Kapp Toscana Group. At this boundary, marine organic-rich mudstones, often forming an upward-coarsening succession, are overlain by grey prodelta shales, with siderite nodules of the Kapp Toscana
Group (Mørk et al. 1982; Mørk et al. 1999). In Svalbard, this boundary approximates to the Ladinian-Carnian transition (Weitschat \& Dagys 1989; Dagys \& Weitschat 1993). In the southern Barents Sea the correlative boundary is located at the base of the Snadd Formation in the earliest Ladinian (Van Veen et al. 1992; Vigran et al. 1998; Mørk et al. 1999), and on Bjørnøya at the base of the Skuld Formation within the Ladinian (Mørk et al. 1990).

The Botneheia Formation core from the Kong Karls Land east section consists of dark shales with a high organic content. It contains phosphate nodules and is very similar to the Botneheia Formation exposed on Edgeøya. The algae Tasmanites are very abundant at some levels (Fig. 8; see Vigran et al. 2008 [this issue]). The main difference from Edgeøya is the presence of cherty nodules, probably originating from the skeletal material
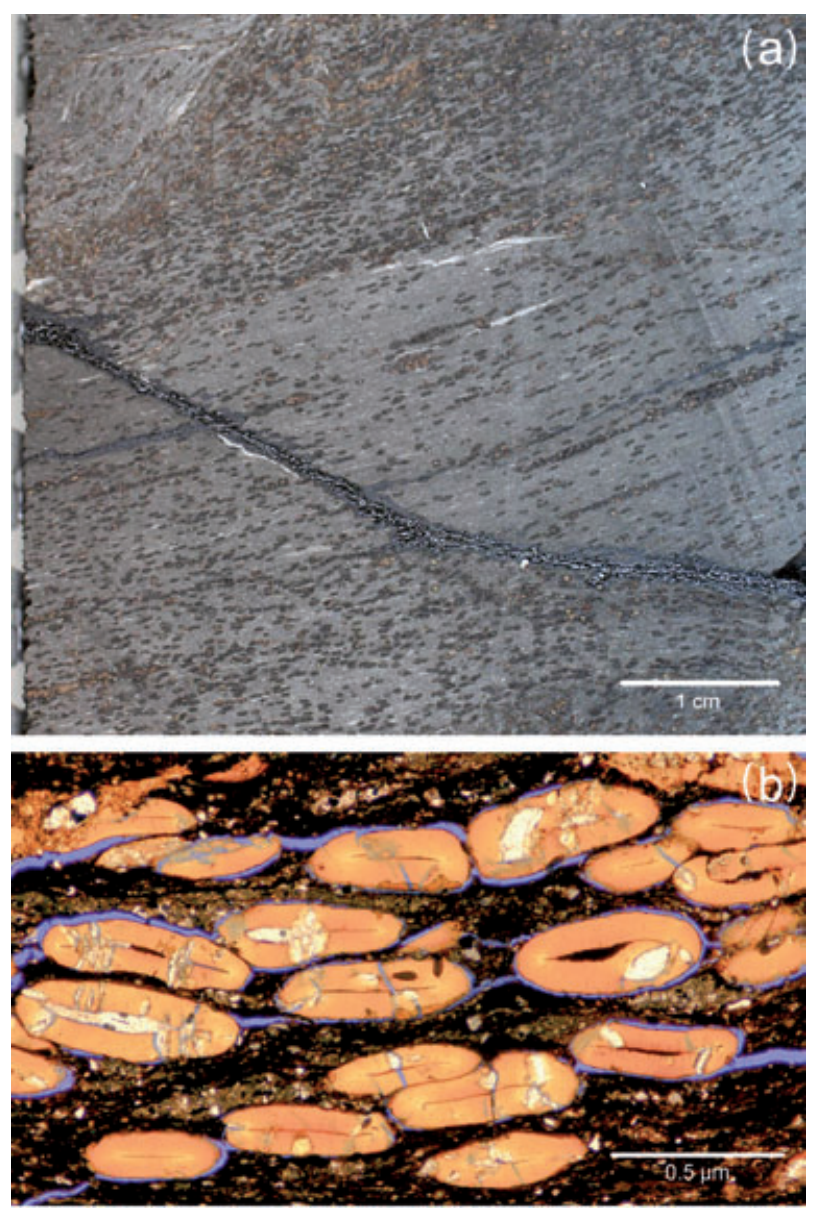

Fig. 8 (a) Occurrence of Tasmanites in the core from eastern Kong Karls Land. Dark-grey claystone with horizontal lamination cause by the accumulation of algal thalli. (b) Thin-section photograph from the same level as (a), showing the flattened algal thalli of Tasmanites stems within a dark clay matrix. 
of siliceous sponges. This may indicate deposition in a deeper, more distal shelf position than the Botneheia Formation on Edgeøya.

The transition between the Botneheia and Tschermakfjellet formations was not cored in the Kong Karls Land east section, as the two adjacent cores are separated by an undrilled section, estimated to be between a few metres and $30 \mathrm{~m}$ thick.

In the Kong Karls Land area, the top of the Botneheia Formation is a prominent seismic reflector that can be traced towards the west. The outcrops of the Botneheia Formation at the sea floor are typically associated with topographic highs, which apparently have resisted glacial erosion. This observation indicates that the wellcemented top of the Botneheia Formation observed in the core may be widespread in the area. East of the drilling area, the seismic quality is poor because of shallow basaltic intrusions close to the sea floor, and so the seismic tie is uncertain.

The lowermost part of the cored succession above the Botneheia Formation also consists of dark shales, and the change in lithology is more subtle than between the Botneheia Formation and the Tschermakfjellet Formation on Edgeøya. However, unpublished geochemical analyses by SINTEF Petroleum Research show that the organic content of the overlying unit is significantly lower than in the Botneheia Formation. The dark shales of this overlying unit bear no resemblance to the contemporaneous shallow shelf/deltaic sediments found further south-east in the Barents Sea, as described from stratigraphic cores on Sentralbanken High, and from exploration wells further south. Lithologically, it can be compared with the uppermost parts of the Botneheia Formation and the Tschermakfjellet Formation, as seen on Edgeøya (Lock et al. 1978; Mørk et al. 1982; Mørk et al. 1999), although in a more offshore development, and is interpreted as a distal part of the Tschermakfjellet Formation, deposited in a deep shelf environment. On Svalbard, the transition from the Botneheia Formation to the Tschermakfjellet Formation is sharp, and is interpreted as a shallowing of the basin from deep shelf to prodeltaic conditions (Mørk et al. 1982; Mørk et al. 1999). In the distal position of the drilled area, this shallowing may not have been equally distinct, resulting in a more subtle change in lithology from one formation to the next.

\section{The De Geerdalen and Snadd formations}

The Tschermakfjellet Formation in the Kong Karls Land east section is overlain by a unit with a pronounced change in lithology. It contains silt and abundant coal debris, indicating a similar transition as that observed from the Tschermakfjellet to the De Geerdalen formations on Edgeøya (Flood et al. 1971; Lock et al. 1978; Mørk et al. 1982; Mørk et al. 1999). The unit was deposited in a shallow shelf environment, and is regarded as the De Geerdalen Formation, although it may also be regarded as the first occurrence of the Snadd Formation, prograding into the area from the south-east (see below). Seismic and palynological interpretations indicate that sediment input was dominantly from the south and the east; however, this trend is more evident higher up in the succession. The transition to the overlying unit has not been cored.

The overlying and dominant part of the cored interval is seismically and palynologically correlated with the Snadd Formation, as defined in the southern Barents Sea and in the Sentralbanken High. It is dated as Early Carnian, with its topmost part passing into the early Late Carnian. A summary of the core description is presented in Fig. 6, and according to our interpretation, the Snadd Formation starts with a deep shelf environment passing upwards into a more proximal open marine environment, followed by an approximately 200-m-thick deltaic succession. The depositional environments of the deltaic succession range from shallow shelf and prodelta, to delta front and interdistributary bay. These are developed as repeated upward-shallowing units, most likely as a result of the autocyclic switching of lobes within one major delta system. On top of the deltaic succession a transgression, anticipated to be regional in character, and which can also be identified in the seismic data, took place, and a new regressive unit evolved, which can be seen in the cores to have started with an open shelf depositional environment, passing upwards into shallow shelf conditions.

The seismic data show a well-developed Carnian clinoform belt trending WSW-ENE in the drilling area (profile B in Fig. 5b, c). The clinoforms dip to the north-west, and seem to be particularly well developed in the upper Carnian succession. Their dimensions are similar to those described for the middle Triassic (Fig. 5c). The clinoform belt extends out of our study area in the east, and is well developed towards the west beyond Kong Karls Land. Towards the north, the clinoform belt is truncated by glacial erosion towards Nordaustlandet. Our interpretation of these seismic data is that the Carnian delta system was prograding towards the north-west into a deep shelf area in the north.

\section{Regional comparison of sandstone compositions of the De Geerdalen and Snadd formations}

In Svalbard, Triassic rocks are exposed along the western Cenozoic fold-belt, in central Spitsbergen, and on the 
eastern islands of Wilhelmøya, Barentsøya, Edgeøya and Hopen, as well as in small exposure areas on southwesternmost Nordaustlandet. The northern parts of Spitsbergen and Nordaustlandet, where large areas with pre-Caledonian rocks are exposed (Hjelle $\delta$ Lauritzen 1982; Lauritzen \& Ohta 1984), have been considered as possible provenance areas for the De Geerdalen Formation in Svalbard and the northern Barents Sea (Birkenmajer 1977; Lock et al. 1978; Mørk et al. 1982). However, the northernmost Triassic exposures on Spitsbergen, Barentsøya and Wilhelmøya show no more proximal development than the exposures further south (Mørk et al. 1982). Based on our seismic observations east and south of Svalbard, outcrop data from Svalbard, and the two corehole sections presented here, we suggest as a new hypothesis that the late Triassic infilling of the northern Barents Sea and Svalbard was sourced from the south and from the east, implying an open seaway to the north. To test this hypothesis, which is mainly derived from seismic interpretation, we have compared mineralogical compositions of the sandstones from the studied cores in the northern Barents Sea with rock data from Svalbard and previously published data from the region.

\section{Sentralbanken and Kong Karls Land east sections}

The very fine- and fine-medium-grained sandstones of the Snadd Formation from the sections studied at the Sentralbanken High and from eastern Kong Karls Land are all characterized by mineralogically immature compositions, rich in feldspar and lithics, in addition to the monogranular quartz (Fig. 9). The Ladinian-lower
Carnian sandstones from the Sentralbanken High, and the lower Carnian sandstones from Kong Karls Land east section, are fairly well to moderately sorted, and have angular to subangular grains. Albite/plagioclase (twinned and untwinned) is typically more abundant than K-feldspar in these locations. Similar rock fragments of chert, volcanic/igneous rocks, and sedimentary and metamorphic rocks are observed in the two cored sections, with chert being the most abundant rock fragment in all samples. Accessory heavy minerals comprise Cr-spinel, zircon, tourmaline and opaque minerals. On the basis of the detrital mineralogy, both differentiated igneous rocks as well as mafic/ultramafic rocks have been eroded in the source area. Garnet is seen in the samples from Sentralbanken, but not from the Kong Karls Land east section. This indicates that metamorphic source areas had more influence on sedimentation at Sentralbanken than in eastern Kong Karls Land.

The sandstones have been somewhat modified by diagenesis, which resulted in the formation of kaolinite, Fe-carbonate, and, in a later stage, pyrite. In the Sentralbanken High, chlorite, quartz and calcite formed relatively late in the paragenetic sequence.

\section{Edgeøya, Svalbard}

A few sandstone samples from the De Geerdalen Formation were collected from outcrops at Blanknuten and Hopen during a reconnaissance expedition in 2007 (Figs. 3a, 6, 1 lb). These samples have lithic arenite compositions, and show similar detrital mineralogy and rock fragments to those described above from the cored
Fig. 9 Comparison of sandstone compositions in shallow drill cores from north-east Kong Karls Land and Sentralbanken (De Geerdalen-Snadd formations) based on petrographic modal analyses. Samples from Edgeøya and Hopen are also included. The lithic grains include polygranular rock fragments, mica and heavy minerals: $F$, fine-grained sandstones; $M$, medium-grained sandstones; VF, very fine-grained sandstones.

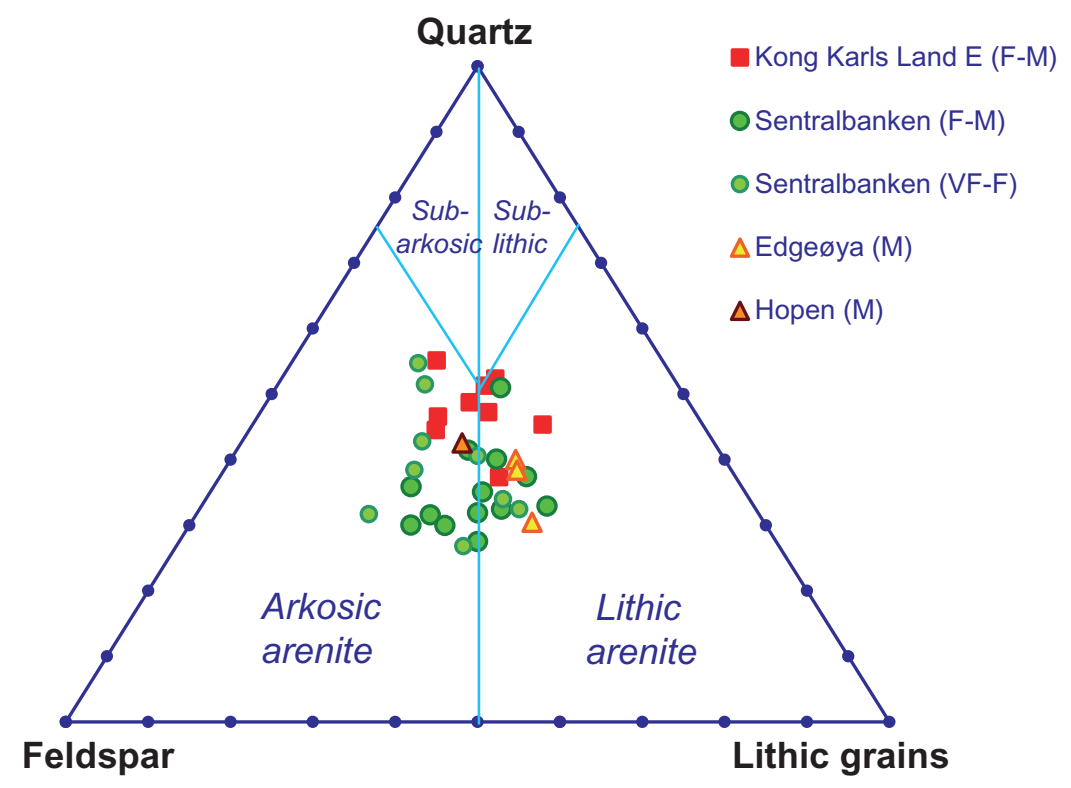


section east of Kong Karls Land and Sentralbanken (Fig. 9). Volcanic/igneous fragments and clay fragments are common. The main accessory heavy minerals are Cr-spinel, zircon, rutile and tourmaline. Garnet was not observed, but has been recorded in the De Geerdalen Formation elsewhere at Edgeøya (Flood et al. 1971). Sandstone samples from the De Geerdalen Formation at Festningen in west Spitsbergen are also mineralogically immature (Mørk 1999), and include similar heavy minerals to those found on Edgeøya.

\section{Franz Josef Land}

Upper Triassic sandstones in Franz Josef Land were interpreted by Dibner (1957) and Pčelina (1988) to have a provenance from the north-east, based on thickness variations, facies distributions and mineralogy. Cherty grains are abundant, as in the north-western Barents Sea, but heavy minerals differ by common garnet and low Cr-spinel (Mørk 1999), probably reflecting a higher proportion of pelitic schists and granitic gneisses being eroded in the source area.

\section{Central southern Barents Shelf}

Triassic sandstone compositions in the central and southern Barents Sea show an increase in mineralogical maturity from the Lower and Middle Triassic to the Upper Triassic (Mørk 1999). These sandstones have higher $\mathrm{K}$-feldspar/plagioclase ratios than are found in our study area, and show more garnet-rich heavy mineral compositions. Metamorphic schists or gneisses and granitic rocks were important sediment sources, supporting erosion of the Caledonides along Baltoscandia (Mørk 1999). However, chert fragments are also common, and volcanic fragments are also present, suggesting additional sources that could have been located more centrally in the Barents Sea, or could be related to northern extensions of the Uralides. It should be taken into account that the cored parts of the Snadd Formation tend to be more fine-grained than the overlying and underlying formations, e.g., in the Nordkapp Basin (Bugge et al. 2002), and also comprise mudstones, siltstones or very fine sandstones in more central areas at the Bjarmeland Platform, Gardarbanken High, Bjørnøya and Hopen. Cr-spinel, rutile, zircon and tourmaline are common heavy minerals in these very fine-grained sandstones.

\section{Sources of chert and volcanic clasts}

In the sandstones studied, both mafic and felsic volcanic rocks are present as rock fragments. In the southern Barents Sea it has been suggested that chert and volcanic components in the Lower and Middle Triassic sandstones could have originated from extensions of the Uralides in the south-east, and in the Upper Triassic sandstones such components could have been transported from more central and eastern areas of the Barents Sea (Mørk 1999). Granitic and pelitic rock components could have been transported from the Caledonides or Precambrian rocks from the mainland in the south-west, but these components contributed less to deposition north of Sentralbanken.

The sandstones from the Kong Karls Land east and Sentralbanken sections show strong compositional resemblance to the samples from Edgeøya. Flood et al. (1971) recognized rock fragments in the sandstones at Edgeøya that looked similar to the groundmass of volcanics/quartz porphyry of Hecla Hoek at Nordaustlandet. Mafic igneous rocks are exposed east of Nordaustlandet (Lauritzen \& Ohta 1984), and these rocks show some evidence of Na- and Si-metasomatic alterations (Ohta 1978). However, the dominant rocks in the exposed basement areas at Spitsbergen and Nordaustlandet are gneisses and granites, which are less probable as sources for the sandstones in the northern Barents Sea, as these sandstones have low K-feldspar/ plagioclase ratios. Cherts and silicified rocks occur in the Upper Palaeozoic Kapp Starostin Formation, exposed to the south-west on Nordaustlandet (Lauritzen \& Ohta 1984). This formation also has a wide distribution in the offshore areas, but it is not known where it was exposed in Late Triassic times, and as mentioned above, the cherty rock fragments are typical in the Triassic sediments over an enormous area stretching from the northern Barents Sea towards the south-east. The samples studied from Edgeøya show the most distinct influence from volcanic/igneous sediment sources consisting of both mafic and felsic rocks, but more comprehensive studies are needed to identify the volcanic source areas. The feldspar types in all of the northern areas indicate a larger contribution from basic and intermediate, rather than acidic, compositions compared with the south-western Barents Sea, and contributions from the Caledonides were less, except for some influence in the Sentralbanken area.

In conclusion, the petrographic and mineralogical studies on Upper Triassic samples from the offshore coreholes, and east Svalbard outcrops, show lithic arkosic sandstone compositions, including some characteristic provenance components of cherty rocks, felsic and mafic igneous/ volcanic (and metamorphic) rocks, which are similar over the entire area. Some regional differences in feldspar types and metamorphic components of the Upper Triassic sandstones across large areas of the Barents Sea reflect stronger contributions from the Caledonides in the southern 
Barents Sea, and from mafic igneous rocks, probably derived from the east in the northern Barents Sea.

\section{Palaeogeography}

In Fig. 10 our interpretation of the north Barents Sea data is integrated into a regional palaeogeographic setting. The three maps (Fig. 10) show how the Early Triassic basin was gradually filled in by large volumes of sediment from source areas in the east and in the south, and by smaller volumes from the west and north-west. The interpretation of depositional environments is based on the shallow core data presented in this paper, whereas their geographic distribution is based on the interpretation of the main seismic facies, as described above, and on exposures on Svalbard. Petrographic studies have contributed to distinguishing between the different source areas.

The position of the western boundary of the Triassic basin is based on the plate reconstruction by Cocks $\&$ Torsvik (2007). South of Spitsbergen there are no observations constraining this position, as the western margin of the Barents Sea is too deeply buried to allow seismic interpretation of the Triassic.

In Fig. 10d the red lines show the eastern boundaries of the deeper shelf area, based on the foot of the slope of the Anisian and Carnian-Ladinian clinoform belts, respectively. The blue lines within the rectangle show the results from a more detailed seismic study (in progress), where the upper break of the slope of each clinoform has been interpreted for a series of clinoforms. The oldest clinoforms to the south-east have an Anisian age, and they are progressively younger towards the north-west, where they reach a late Carnian age. The rectilinear geometry of the clinoform belt, and its advance to the west caused by rapid deposition, indicate that the main sediment input came from the east and south-east. This interpretation challenges the suggestion of Doré (1991) that the North and South Barents Sea basins had sufficient accommodation space to stop large sediment volumes from prograding across these basins, and further into the western Barents Sea.

\section{Anisian}

In the Anisian, the distribution of the deep shelf areas is constrained by the clinoform belt (Fig. 10a). In the deep shelf, organic-rich and phosphatic shales equivalent to the Botneheia Formation were deposited.

The sandy Kobbe Formation (Worsley et al. 1988) has its type well in the extreme south of the western Barents Sea, and our seismic interpretation suggests a sediment source to the south in this area. The Kobbe Formation as recognized here has a limited distribution in the southern
Hammerfest Basin. It is implied in Fig. 10a that the Hammerfest Basin is an area where sediments could have been derived both from the southern and ESE source areas. North of approximately $72^{\circ} \mathrm{N}$, the clinoform pattern indicates that the eastern source predominates. The Loppa and Stappen structural highs, which were uplifted during Permian tectonism, acted as topographical highs as late as the Anisian and Ladinian, and received very little sediment. Well data from the crest of the Loppa High show that the Snadd Formation rests on Permian carbonates, suggesting that the high may have been exposed until the Ladinian (Gading 1993; Worsley et al. 2001; Larssen et al. 2005; Worsley 2008). The SørkappHornsund High at Svalbard is a similar feature (Dallmann et al. 1993), although it was submerged somewhat earlier. Based on the shallow cores and the seismic facies, the area indicated as delta-front sediments in the Anisian is mapped to have a wider distribution than the Ladinian and Carnian delta-front systems. This suggests a relatively higher rate of subsidence or lower rate of deposition in the Anisian than in the later periods.

\section{Ladinian}

The Ladinian transition from shallow to deep shelf (Fig. 10b) is not as well constrained by seismic data as is the Anisian. This results from a deterioration of seismic quality towards Svalbard, and from the less reflective and sometimes more chaotic character of the clinoform belt that makes it more difficult to identify in poor seismic data. The cores from eastern Kong Karls Land confirm that a deep shelf facies existed in the latest Ladinian. The high siliceous content, probably derived from sponges, is interpreted to suggest a deeper environment for the Kong Karls Land east core than for correlative beds in Svalbard. In the Sentralbanken cored section, a late Ladinian regression gave way to a channelled seismic facies, interpreted as having been deposited in a tidal environment (Fig. 7). As shown in Fig. 4c, the thick upper Ladinian and Carnian paralic deposits, which were cored in Sentralbanken, correspond with a regionally distributed, heterogeneous, channelled seismic facies. Based on this seismic interpretation, a palaeogeographic setting is suggested, where sediments sourced from the ESE approached the Svalbard area in the late Ladinian (Fig. 10b). In the Svalbard Archipelago, deposition of dark, organic-rich shales of the Botneheia Formation continued until the Ladinian-Carnian boundary, with some input of coarser clastic sediments from the west.

\section{Carnian}

The mapped distribution and dip direction of the Carnian clinoform belt shown in Fig. 10c has been used to 

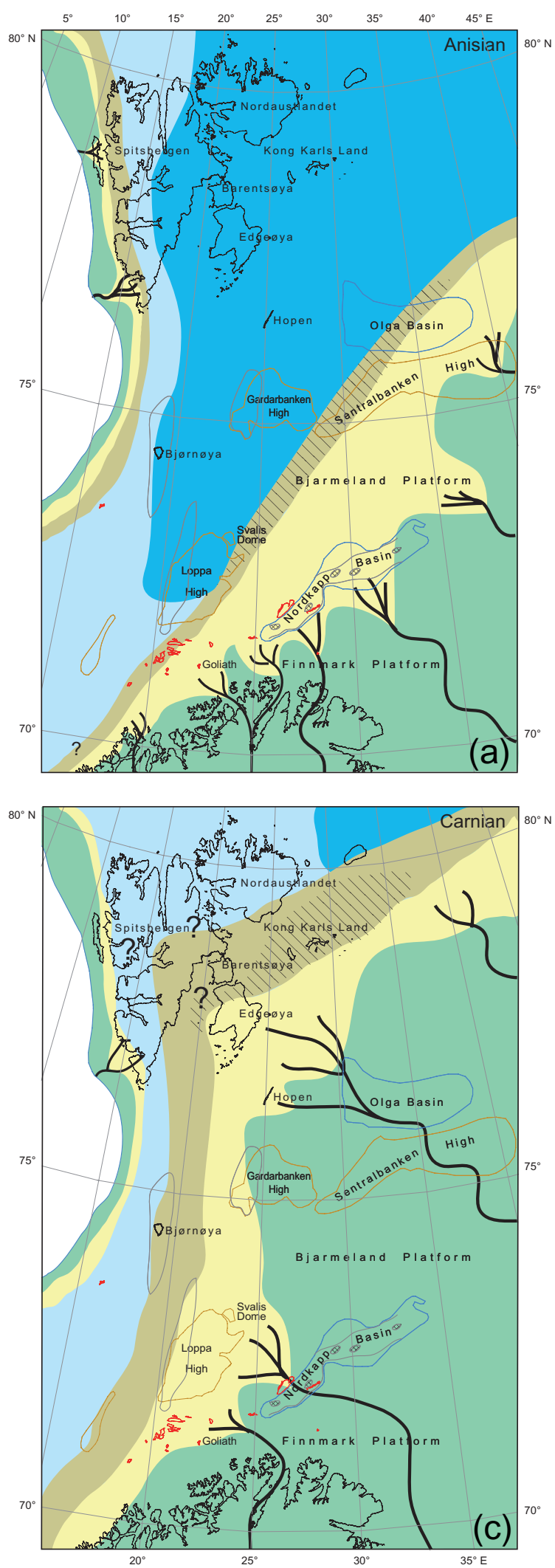

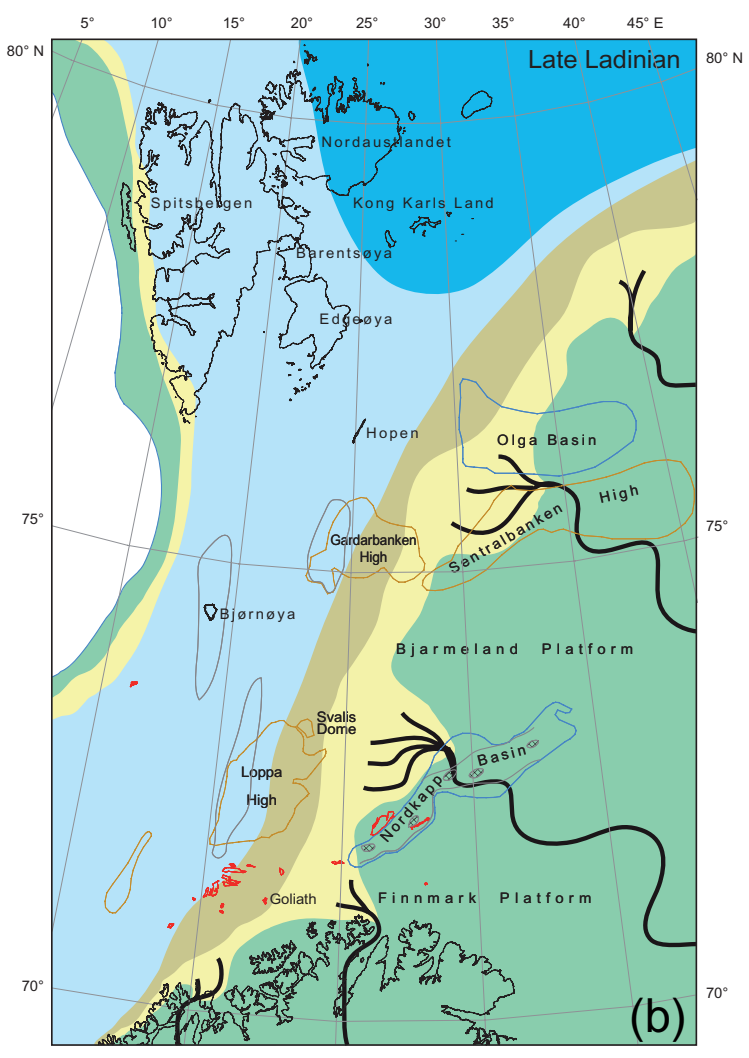

\begin{tabular}{|l|l|l|}
\hline \multicolumn{2}{|l|}{ Depositional environments } & \multicolumn{2}{c|}{ Structural elements } \\
\hline & Delta plain & Clinoforms \\
\hline & Deltaic / Fluvial & High (recent) \\
Prodelta & Basin (recent) \\
\hline & Shallow shelf & Palaeohigh \\
\hline & Deep shelf & Field / discovery \\
\hline & Salt diapir & \\
\hline
\end{tabular}

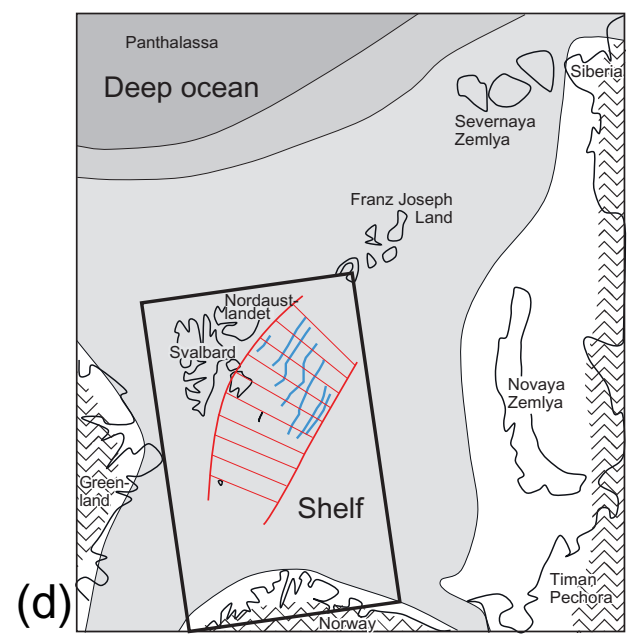


Fig. $10(\mathrm{a}-\mathrm{c})$ Palaeogeographic maps showing the progradation of sediments into the Middle Triassic marine embayment, and the development of a paralic platform in the Late Triassic. In the maps, the detailed boundaries between depositional areas are simplified, and the positions of the rivers are conceptual. (d) Overview map showing the interpreted progradation of shallow shelf/delta-front areas across the study area in the Barents Sea from Anisian (red line to the east) to Carnian times (red line to the west). Blue lines show seismically interpreted Anisian, Ladinian and Carnian clinoform breaks within the study area. Wavy lines show the main sediment source areas suggested in the text. The position of the continents is redrawn from Cocks \& Torsvik (2007), see Fig. 1. The rectangle shows the location of the maps in (a-c).
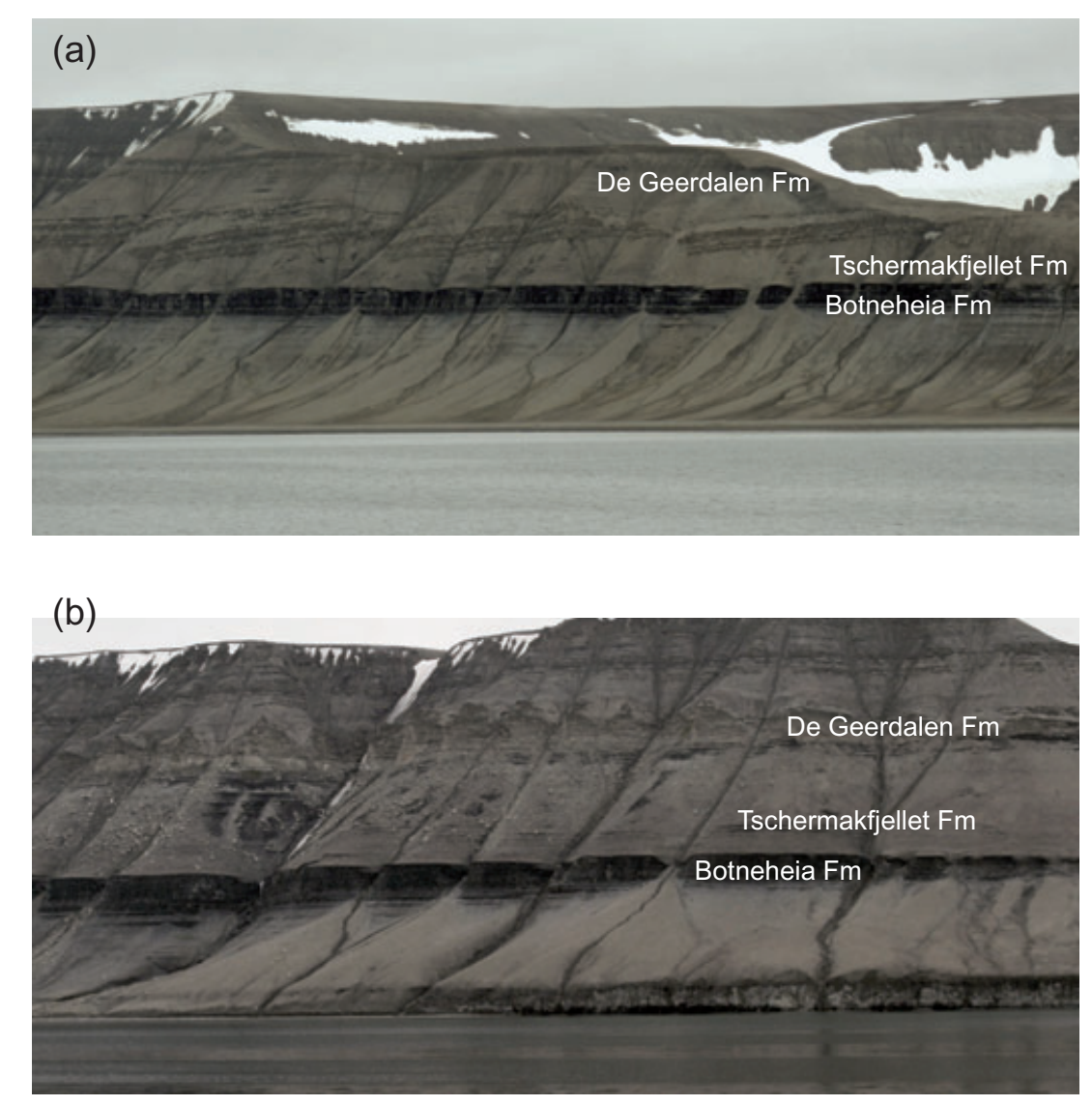

Fig. 11 (a) Outcrop of the Botneheia, Tschermakfjellet and De Geerdalen formations at Klinkhammaren, north-west Edgeøya, with northwards dipping beds caused by rotation resulting from growth faults in the Tschermakfjellet Formation and lower part of the De Geerdalen Formation. The total thickness of the dipping strata is $100-150 \mathrm{~m}$. (b) Outcrop at Blanknuten, north-west Edgeøya, with deltaic sandstones in the middle part of the De Geerdalen Formation. The thickness of the Tschermakfjellet Formation is approximately $50 \mathrm{~m}$. North is to the left in both panels.

constrain the Carnian prodelta area, and the remaining areas of deep shelf, which were located north of the clinoform belt. The dimensions of the individual clinoforms are similar to the Middle Triassic clinoforms, and a similar water depth in the deep shelf areas is suggested. Hence, our regional seismic data show a continuing Carnian progradation towards the north and north-west, into deeper waters in the areas east of Svalbard, including Kong Karls Land (Figs. 5c, 10c).

Within the Svalbard Archipelago, the situation is more complex. In eastern Svalbard, the Tschermakfjellet Formation prograded over the Botneheia Formation in the earliest Carnian (Lock et al. 1978; Mørk et al. 1982). There is a considerable increase in thickness from the Carnian succession of the De Geerdalen and Tschermakfjellet formations in Svalbard, to the areas east of Kong
Karls Land, where the total Carnian thickness exceeds $1000 \mathrm{~m}$ (Figs. 5a, c). In eastern Svalbard, the typical thickness of the Tschermakfjellet Formation combined with the prodeltaic lower part of the De Geerdalen Formation is in the order of $100 \mathrm{~m}$ (Fig. 1 la), compared with approximately $400 \mathrm{~m}$ in the seismically interpreted clinoform belt east of Kong Karls Land (Fig. 5c). The thickness increase implies a larger accommodation space east of Svalbard, which could be related to a deeper shelf prior to the deltaic infilling. The interpretation is also consistent with the interpretation of a deeper water environment of the uppermost Botneheia Formation in the core east of Kong Karls Land, than in eastern Svalbard.

In Kvalpynten, south-western Edgeøya, a transport direction with a component from the north seems to be supported by spectacular exposures of growth faults in 
the Lower Carnian section described by Edwards (1976). The true dip directions of these growth faults were not measured, but in the north-south-trending cliff, the fault traces dip towards the south, with a few exceptions. The sediments that were exposed to growth faulting are described as four upward-coarsening deltaic sequences (Edwards 1976). Their accumulated thickness is in the order of $100 \mathrm{~m}$. This transport direction is opposite to the regional direction obtained from seismic interpretation in the neighbouring Barents Sea.

Additional fieldwork was carried out in eastern Svalbard in 2008 to reconstruct the Late Triassic palaeogeography in this area. Preliminary results appear to be consistent with the observations by Knarud (1980), who reported a predominance of sediment transport directions from easterly directions in the deltaic sediments of the De Geerdalen Formation. According to our observations, growth faults in the Tschermakfjellet and De Geerdalen formations could be widely distributed on Edgeøya (Fig. 11a). Faults with dip directions towards the north as well as to the south seem to be common, and the relationship between the growth faults and the sediment progradation needs to be investigated further. The question marks in Fig. 10c indicate that the palaeogeography of the early Carnian of eastern Svalbard is not yet resolved. Sediment transport from the WNW, as well as from the south-east, should be considered as possible.

Figure 10c implies that in the Carnian, the original Early Triassic shelf area was almost filled in by Triassic sediments prograding from its south-eastern, southern and western margins. More information about the details of the possible closure of the seaway across Svalbard could be sought in the outcrops on the Spitsbergen Archipelago, and in the sediments underlying the central Spitsbergen Cenozoic Basin.

\section{Summary and conclusions}

Interpretation of an extensive dataset of deep seismic profiles and shallow stratigraphic cores has resulted in new information about the development of the Middle and Late Triassic succession, in the northern Barents Shelf and eastern Svalbard. Mapping of seismic clinoforms suggest that after the late Early Triassic (Olenekian), the western Barents Sea shelf was infilled through a largescale deltaic progradation from sediment sources located to the ESE. The clinoform belt represents the slope that separated a deep shelf area with deposition of organicrich, phosphatic shales in the west (Botneheia and Steinkobbe formations) from the delta-front area in the east (Kobbe and Snadd formations). In the time period from the Olenekian to the Carnian, progressively larger areas were covered by shallow shelf and paralic deposits. As a result of this progradation, Middle and Upper Triassic formational boundaries are diachronous, being older in the south-east than in the north-west. Our interpretation of seismic data from the south-western Barents Sea indicates that prior to this Middle-Late Triassic progradation, a southern, Baltoscandian sediment source prevailed in the Early Triassic.

These new paleogeographic reconstructions of the Late Triassic in the northernmost Barents Sea imply that previous reconstructions, which did not have access to the regional seismic data, tended to underestimate the volume of sediments sourced from the ESE, and to overestimate the importance of sources from the west and north. In our reconstruction, a Triassic open marine shelf area existed on Svalbard and in the northernmost Barents Sea until the earliest Carnian. In that time period, sediment input to Svalbard mainly came from the western margin (Mørk et al. 1999). As a result of further progradation from the ESE, a continuous paralic shelf area extended from the Barents Sea to Svalbard (the De Geerdalen Formation in Svalbard, and the Snadd Formation in the Barents Sea) in the late Carnian. Our palaeogeographic reconstruction based on seismic data, shallow coreholes and correlation with Svalbard outcrop data indicates that the Snadd and De Geerdalen formations coalesced and formed a continuous depositional system. The diachronous lower boundary of this system is caused by progradation across a large part of the Barents Sea shelf. Some uncertainty remains for south-western Spitsbergen, where a local western sediment source is indicated by Mørk et al. (1982), and further north in Svalbard, where a source area from the WNW cannot be excluded.

\section{Acknowledgements}

We thank the Norwegian Petroleum Directorate for giving permission to publish the core and seismic data. Palynological datings have been carried out by SINTEF Petroleum Research, and by Applied Petroleum Technology. We appreciate the comments and suggestions from Snorre Olaussen, David Worsley and one anonymous reviewer, whose contributions have significantly improved the paper.

\section{References}

Bergan M. \& Knarud R. 1992. Apparent changes in clastic mineralogy of the Triassic-Jurassic succession, Norwegian Barents Sea: possible implications for palaeodrainage and subsidence. In T.O. Vorren et al. (eds.): Arctic geology and petroleum potential: proceedings of the Norwegian Petroleum 
Society Conference, 15-17 August 1990, Tromsø, Norway. Pp. 481-493. Amsterdam: Elsevier.

Birkenmajer K. 1977. Triassic sedimentary formations of the Hornsund area, Spitsbergen. Studia Geologica Polonica 51, $1-74$.

Bugge T., Elvebakk G., Fanavoll S., Mangerud, G., Smelror M., Weiss H.M., Gjelberg J., Kristensen S.E. \& Nilsen K. 2002. Shallow stratigraphic drilling applied in hydrocarbon exploration of the Nordkapp Basin, Barents Sea. Marine and Petroleum Geology 19, 13-37.

Cocks L.R.M.\& Torsvik T.H. 2007. Siberia, the wandering northern terrane, and its changing geography through the Palaeozoic. Earth-Science Reviews 82, 29-74.

Dagys A. \& Weitschat W. 1993. Correlation of the Boreal Triassic. Mitteilungen Geologisch-Paläontologisches Institut Universität Hamburg 75, 249-256.

Dallmann W.K., Andresen A., Bergh S.G., Maher H.D. Jr. \& Ohta Y. 1993. Tertiary fold-and-thrust belt of Spitsbergen, Svalbard. Norsk Polarinstitutt Meddelelser 128. Oslo: Norwegian Polar Institute.

Dibner V.D. 1957. Geologičeskoe stroenie Zemli Franca-Iosifa. (Geological structure of Franz Josef Land.) Trudy Instituta Geologii Arktiki 81, 11-20.

Doré A.G. 1991. The structural foundation and evolution of Mesozoic seaways between Europe and the Arctic. Palaeogeography, Palaeoclimatology, Palaeoecology 87, 441-492.

Edwards M.B. 1976. Growth faults in Upper Triassic deltaic sediments, Svalbard. American Association Petroleum Geologists Bulletin 60, 341-355.

Egorov A.Y. \& Mørk A. 2000. The East Siberian and Svalbard Triassic successions and their sequence stratigraphical relationships. Zentralblatt für Geologie und Paläontologie, Teil 1, 1377-1430.

Embry A.F. 1997. Global sequence boundaries of the Triassic and their identification in the western Canada sedimentary basin. Canadian Petroleum Geology Bulletin 45, 415-433.

Flood B., Nagy J. \& Winsnes T.S. 1971. The Triassic succession of Barentsøya, Edgeøya and Hopen (Svalbard). Norsk Polarinstitutt Meddelelser 100. Oslo: Norwegian Polar Institute.

Gabrielsen R.H., Færseth R.R., Jensen L.N., Kalheim J.E. \& Riis F. 1990. Structural elements of the Norwegian continental shelf, part 1, the Barents Sea region. Norwegian Petroleum Directorate Bulletin 6. Stavanger: Norwegian Petroleum Directorate.

Gading M. 1993. Triassic evolution in the Barents Sea, Norwegian and Russian sectors: a seismic and sequence stratigraphic approach. PhD thesis, Norwegian Institute of Technology, University of Trondheim.

Gramberg I.S. (ed.) 1988: Barentcevskaja Šel'fovaja Plita. (Barents Shelf Plate.) VNIIOkeangeologija Trudy 196. Leningrad: All-Russian Research Institute for Geology and Mineral Resources of the World Ocean.

Hjelle A. \& Lauritzen Ø. 1982. Geological map of Svalbard 1:500,000, sheet 3G, Spitsbergen northern part. Norsk Polarinstitutt Skrifter 154C. Oslo: Norwegian Polar Institute.
Johansen S.E., Ostisty B.K., Birkeland Ø., Fedorovsky Y.F., Martirosjan V.N., Bruun Christensen O., Cheredeev S.I., Ignatenko E.A. \& Margulis L.S. 1992. Hydrocarbon potential in the Barents Sea region: play distribution and potential. In T.O. Vorren et al. (eds.): Arctic geology and petroleum potential: proceedings of the Norwegian Petroleum Society Conference, 15-17 August 1990, Tromsø, Norway. Pp. 273-320. Amsterdam: Elsevier.

Knarud R. 1980. En sedimentologisk og diagenetisk undersøkelse av Kapp Toscana Formasjonens sedimenter på Svalbard. (A sedimentological and diagenetic study of the sediments of the Kapp Toscana Formation in Svalbard). Cand. real. thesis, University of Oslo.

Krajewski K.P. 2000. Phosphogenic facies and processes in the Triassic of Svalbard. Studia Geologica Polonica 116, 7-84.

Larssen G.B., Elvebakk G., Henriksen L.B., Kristensen E., Nilsson I., Samuelsberg T.J. \& Stemmerik L. 2005. Upper Palaeozoic lithostratigraphy of the southern Norwegian Barents Sea. Norges Geologiske Undersøkelser Bulletin 444. Trondheim: Geological Survey of Norway.

Lauritzen Ø. \& Ohta Y. 1984. Geological map Svalbard 1:500 000, Sheet $4 G$ Nordaustlandet. Norsk Polarinstitutt Skrifter 154D. Oslo: Norwegian Polar Institute.

Laursen I., Solli K., Gytri S.R., Larssen G.B., Ryseth A.E. \& Sandvoll. T. 2006. Triassic reservoir distribution and depositional environments recognized by high resolution seismic imaging in southwestern Barents Sea. In H.A. Nakrem \& A. Mørk (eds.): Boreal Triassic 2006. Longyearbyen, Svalbard, 16-19 August 2006. NGF Abstracts and Proceedings of the Geological Society of Norway 3, 92-94.

Leith T.L., Weiss H.M., Mørk A., Århus N., Elvebakk G., Embry A.F., Stewart K.R., Pchelina T.M., Bro E.G., Verba M.L., Danyushevskaya A. \& Borisov A.V. 1992. Mesozoic hydrocarbon source-rocks of the Arctic region. In T.O. Vorren et al. (eds.): Arctic geology and petroleum potential: proceedings of the Norwegian Petroleum Society Conference, 15-17 August 1990, Tromsø, Norway. Pp. 1-25. Amsterdam: Elsevier.

Lock B.E., Pickton C.A.G., Smith D.G., Batten D.J. \& Harland W.B. 1978. The geology of Edgeøya and Barentsøya, Svalbard. Norsk Polarinstitutt Skrifter 168. Oslo: Norwegian Polar Institute.

Mørk A., Dallmann W., Dypvik H., Johannessen E.P., Larssen G.B., Nagy J., Nøttvedt A., Olaussen S., Pčelina T.M. \& Worsley D. 1999. Mesozoic lithostratigraphy. In W.K. Dallmann (ed.): Lithostratigraphic Lexicon of Svalbard. Upper Palaeozoic to Quaternary bedrock. Review and recommendation for nomenclature use. Pp. 127-214. Tromsø: Norwegian Polar Institute.

Mørk A. \& Elvebakk G. 1999. Lithological description of subcropping Lower and Middle Triassic rocks from the Svalis Dome, Barents Sea. Polar Research 18, 83-104.

Mørk A., Embry A.F. \& Weitschat W. 1989. Triassic transgressive-regressive cycles in the Sverdrup Basin, Svalbard and the Barents Shelf. In J.D. Collinson (ed.): Correlation in hydrocarbon exploration. Pp. 113-130. London: Graham \& Trotman. 
Mørk A., Knarud R. \& Worsley D. 1982. Depositional and diagenetic environments of the Triassic and Lower Jurassic succession of Svalbard. In A.F. Embry \& H.R. Balkwill (eds.): Arctic geology and geophysics: proceedings of the Third International Symposium on Arctic Geology. Pp. 371-398. Calgary: Canadian Society of Petroleum Geologists.

Mørk A. \& Smelror M. 2001. Correlation and non-correlation of high order circum-Arctic Mesozoic sequences. Polarforschung 69, 65-72.

Mørk A., Vigran J.O. \& Hochuli P.A. 1990. Geology and palynology of the Triassic succession of Bjørnøya. Polar Research 8, 141-163.

Mørk A., Vigran J.O., Korchinskaya M.V., Pchelina T.M., Fefilova L.A., Vavilov M.N. \& Weitschat W. 1992. Triassic rocks in Svalbard, the Arctic Soviet islands and the Barents Shelf: bearing on their correlations. In T.O. Vorren et al. (eds.): Arctic geology and petroleum potential: proceedings of the Norwegian Petroleum Society Conference, 15-17 August 1990, Tromsø, Norway. Pp. 457-479. Amsterdam: Elsevier.

Mørk M.B.E. 1999. Compositional variations and provenance of Triassic sandstones from the Barents Shelf. Journal of Sedimentary Research 69, 690-710.

Norwegian Petroleum Directorate (NPD) 2008. Exploration wellbore: 7226/11-1. NPD factpages. Accessed on the internet at http://www.npd.no/engelsk/cwi/pbl/en/index.htm on 24 September 2008.

Ohta Y. 1978. Caledonian basic rocks of Storøya and Kvitøya, NE Svalbard. Norsk Polarinstitutt Årbok 1977, 25-42.

Pčelina [Pchelina] T.M. 1988. The Mesozoic sedimentary complexes. Chapters 6.1 and 9.7. In I.S. Gramberg (ed.) 1988: Barentcevskaja Šel'fovaja Plita. (Barents Shelf Plate.) VNIIOkeangeologija Trudy 196. Pp. 142-157, 211-218. Leningrad: All-Russian Research Institute for Geology and Mineral Resources of the World Ocean.

Rasmussen A., Kristensen S.E., Van Veen P., Stølan T. \& Vail P.R. 1993. Use of sequence stratigraphy to define a semi-stratigraphic play in Anisian sequences, southwestern Barents Sea. In T.O. Vorren et al. (eds.): Arctic geology and petroleum potential: proceedings of the Norwegian Petroleum
Society Conference, 15-17 August 1990, Tromsø, Norway. Pp. 439-456. Amsterdam: Elsevier.

Rise L. \& Sættem J. 1994. Shallow stratigraphic wireline coring in bedrock offshore Norway. Scientific Drilling 4, 343-257.

Rønnevik H.C \& Jacobsen H.P 1984. Structural highs and basins in the western Barents Sea. In A.M. Spencer et al. (eds.): Petroleum geology of the North European Margin. Pp. 19-32. London: Graham \& Trotman.

Van Veen P.M., Skjold, L.J., Kristensen, S.E., Rasmussen, A., Gjelberg, J. \& Stølan T. 1992. Triassic sequence stratigraphy in the Barents Sea. In T.O. Vorren et al. (eds.): Arctic geology and petroleum potential: proceedings of the Norwegian Petroleum Society Conference, 15-17 August 1990, Tromsø, Norway. Pp. 515-538. Amsterdam: Elsevier.

Vigran J.O., Mangerud G., Mørk A., Bugge T. \& Weitschat W. 1998. Biostratigraphy and sequence stratigraphy of the Lower and Middle Triassic deposits from the Svalis Dome, central Barents Sea, Norway. Palynology 22, 89-141.

Vigran J.O., Mørk A., Forsberg A.W., Weiss H.M. \& Weitschat W. 2008. Tasmanites algae-contributors to the Middle Triassic hydrocarbon source rocks of Svalbard and the Barents Shelf. Polar Research 27, 360-371.

Weitschat W. \& Dagys A.S. 1989. Triassic biostratigraphy of Svalbard and comparison of northeast Siberia. Mitteilungen Geologisch-Paläontologisches Institut der Universität Hamburg $68,179-213$.

Worsley D. 2008. The post-Caledonian development of Svalbard and the western Barents Sea. Polar Research 27, 298-317.

Worsley D., Agdestein A., Gjelberg J.G., Kirkemo K., Mørk A., Nilsson I., Olaussen S., Steel R.J. \& Stemmerik L. 2001. The geological evolution of Bjørnøya, Arctic Norway: implications for the Barents Shelf. Norwegian Journal of Geology 81, 195-234.

Worsley D., Johansen R. \& Kristensen S.E. 1988. The Mesozoic and Cenozoic succession of Tromsøflaket. In A. Dalland et al. (eds.): A lithostratigraphic scheme for the Mesozoic and Cenozoic succession offshore mid- and northern Norway. Norwegian Petroleum Directorate Bulletin 4, 42-65. Stavanger: Norwegian Petroleum Directorate. 